Article

\title{
Timing and Metamorphic Evolution of the Ross Orogeny in and around the Mountaineer Range, Northern Victoria Land, Antarctica
}

\author{
Sang-Bong Yi * ${ }^{\mathbb{D}}$, Mi Jung Lee ${ }^{\mathbb{D}}$, Jong Ik Lee and Hwayoung Kim \\ Division of Polar Earth-System Sciences, Korea Polar Research Institute, Incheon 21990, Korea; \\ mjlee@kopri.re.kr (M.J.L.); jilee@kopri.re.kr (J.I.L.); gadd1013@snu.ac.kr (H.K.) \\ * Correspondence: handjive@kopri.re.kr
}

Received: 1 September 2020; Accepted: 8 October 2020; Published: 13 October 2020

\begin{abstract}
The Ross(-Delamerian) Orogeny significantly impacted the formation of the tectonic structure of the Pacific Gondwana margin during the early Paleozoic era. Northern Victoria Land (NVL) in Antarctica preserves the aspect of the Ross Orogeny that led to the union of the Wilson (WT)-Bowers (BT)-Robertson Bay Terrane. The aspect of the Ross Orogeny in the NVL is characterized by subduction of oceanic domains toward the continental margin (continental arc) and the accretion of the associated marine-continental substances from 530-480 Ma. In the Mountaineer Range in NVL, the Ross Orogeny strain zone is identified at the WT/BT boundary regions. In these areas, fold and thrust shear zones are observed and aspects of them can be seen at Mt. Murchison, the Descent Unit and the Black Spider Greenschist zone. The Dessent Unit corresponds to a tectonic slice sheared between the WT and BT. The metamorphic evolution phase of the Dessent Unit is summarized in the peak pressure $\left(\mathrm{M}_{1}\right)$, peak temperature $\left(\mathrm{M}_{2}\right)$ and retrograde $\left(\mathrm{M}_{3}\right)$. The sensitive high-resolution ion microprobe (SHRIMP) zircon U-Pb ages of 514.6 $\pm 2.0 \mathrm{Ma}$ and 499.2 $\pm 3.4 \mathrm{Ma}$ obtained from the Dessent Unit amphibolite are comparable to the $\mathrm{M}_{1}$ and $\mathrm{M}_{2}$ stages, respectively. The Dessent Unit underwent intermediate pressure $(\mathrm{P}) /$ temperature $(\mathrm{T})$-type metamorphism characterized by 10.0-10.5 kbar/ 600 ${ }^{\circ} \mathrm{C}\left(\mathrm{M}_{1}\right)$ and $\sim 7 \mathrm{kbar} / \sim 700{ }^{\circ} \mathrm{C}\left(\mathrm{M}_{2}\right)$ followed by $4.0-4.5 \mathrm{kbar} / 450{ }^{\circ} \mathrm{C}\left(\mathrm{M}_{3}\right)$. Mafic to intermediate magmatism (497-501 Ma) within the WT/BT boundary region may have given rise to the $\mathrm{M}_{2}$ stage of the Dessent Unit, and this magmatism is synchronous with the migmatization period of Mt. Murchison ( $498.3 \pm 3.4 \mathrm{Ma}$ ). This indicates that a continuous process of fold-shearing-magmatic intrusion-partial melting, which is typically associated with a continental arc orogeny, occurred before and after c. $500 \mathrm{Ma}$ in the Mountaineer Range. During the Ross Orogeny, the Dessent unit was initially subducted underneath the WT at depth (10.0-10.5 kbar, $\sim 35 \mathrm{~km})$ and then thrust into the shallow $(\sim 7 \mathrm{kbar}, \sim 23 \mathrm{~km})$, hot $\left(\geq 70{ }^{\circ} \mathrm{C}\right)$ magmatic arc docking with the Mt. Murchison terrain, where migmatization prevailed.
\end{abstract}

Keywords: Antarctica; Gondwana margin; Ross Orogeny; Northern Victoria Land; Dessent Unit; tectonic slice

\section{Introduction}

Antarctica comprises Archean to Phanerozoic (Cenozoic) lithologies, which record a dynamic history of the assembly and breakup of supercontinents [1-6]. The basement of East Antarctica is composed of Archean and Proterozoic rocks forming a continental shield through the amalgamation of several cratons (i.e., accretion and collision) during the Precambrian eon (Figure 1) [5,7-9]. Moreover, the East Antarctic Shield played a significant role in its surrounding plates' (e.g., Australian, Kalahari, Indian and Congo Cratons) arrangement and motion during the amalgamation and separation of Gondwana (Figure 1c,d) $[2,4,10,11]$. In the early Paleozoic era, the volume of East Antarctica (or 
the Pacific Gondwana margin) began to increase. This increase occurred from the paleo-Pacific plate's subduction into East Antarctica, causing the accretion of oceanic-continental domains. The subduction and accretion into the Pacific Gondwana margin, which began in the late Neoproterozoic-early Paleozoic era, is termed the Terra Australis Orogen [5,11-13]. The Antarctic-Australian segment of this orogen is referred to as the Ross-Delamerian Orogen, which significantly controlled the geological structures of Antarctica (Transantarctic Mountains (TAM) region), Australia and Tasmania during 530-470 Ma (Figure 1c,d) [3,14-16]. Subsequent subduction and related accretions gradually revealed West Antarctica, a tectonically active region between East Antarctica and the paleo-Pacific Ocean. The Mesozoic subduction of the oceanic domain to eastern Gondwana led to the almost completion of West Antarctica and the Antarctic Peninsula (Figure 1d) [5,17-20]. During the mid- to late-Mesozoic era, Antarctica separated from Gondwana and shifted southward, followed by Australia's separation from Antarctica [19,21-23]. The development of the Cenozoic West Antarctic Rift System [17,19,24,25] marked the completion of Antarctica's geological journey towards the South Pole (Figure 1).

Geological investigations of Antarctica are associated with numerous challenges including the limited exposure of rock outcrops, inaccessibility of field sites and extreme weather conditions. Extensive ice cover is one of the main obstacles for assessing and interpreting petrological formation ages, geological province correlations, deformation timing and plate margin paleogeography and its corresponding history. Nonetheless, geochronological studies on outcrops and clastic materials and interpretations of geophysical data have given rise to a number of informative findings on the major orogenies in Antarctic geological history, as well as the links between Antarctica and the surrounding continents $[2,5,13,26,27]$. The Ross-Delamerian Orogen has remained one of the most important research focal points for understanding the geological history of Antarctica-Australia-Tasmania-New Zealand. This orogen, also referred to as the Ross Orogeny in Antarctica, played a crucial role in the formation of the TAM domain, including Victoria Land (VL) [5,19,28-31]. Northern VL (NVL) had been completed as a result of the Ross Orogeny [32-39].

This study investigates the age and metamorphic condition of the Ross Orogeny at the Wilson Terrane (WT) and Bower Terrane (BT) boundary (Mountaineer Range) in NVL (Figure 1b). We interpret the amalgamation process of the WT-BT based on geological field observations, sensitive high-resolution ion microprobe (SHRIMP) zircon $\mathrm{U}-\mathrm{Pb}$ dating, metamorphic pseudosection analyses and conventional geothermobarometry. In addition, we discuss a proto-sedimentary basin development (late Neoproterozoic to early Paleozoic) process associated with the protolith formation of the Mountaineer Range paragneiss (WT). The early Paleozoic era in the Mountaineer Range is characterized by significant geological events, such as a subduction process in the continental margin, development of continental arc, formation of continental-affinity volcanic arc and continent-volcanic arc collision. A geological journey to the Antarctica of Gondwana begins in the next section.

\section{Geological Outline}

The basement rock bodies of the TAM ( $3000 \mathrm{~km}$ long) were affected by the Ross Orogen, and most of the lithologies of the TAM were also formed during this orogeny $[19,26,40]$. The TAM domain is comprised of the NVL, southern VL, central TAM, southern TAM and Pensacola Mts. areas. In this study, research is carried out on the NVL region. NVL is located at the northern (an Australia-New Zealand direction) end of the TAM and is surrounded by the Ross Sea and the Southern Ocean. Three major fault-bounded tectonostratigraphic terranes, namely the WT, BT and Robertson Bay Terrane (RBT), each of which is considered to be the Ediacaran-Cambrian continental margin, volcanic arc and turbiditic marine sediments, comprise NVL $[33,34,36,39,41,42]$. The Ross Orogeny, a crucial event in the Pacific Gondwana margin's geological change, completed the union of these three terranes. The terranes are divided by the Lanterman Fault (WT/BT boundary) and the Leap Year Fault (BT/RBT boundary; Figure 1b).

The WT basement comprises predominantly metasedimentary rocks, referred to as the Wilson Metamorphic Complex, intruded by the Granite Harbour Intrusives (GHI) [15,31,40,43-46]. The metamorphic complex shows low- to high-T characteristics of the low-P type and crops out 
as schist, gneiss and migmatite. Protoliths of this complex correspond to the recycled passive margin sediments of the East Antarctic basement. The metamorphic complex's protolith age is estimated at late Neoproterozoic to early Paleozoic [36,39,47,48]. The GHI is of Cambrian igneous age (mainly 520-480 Ma) and shows syn- to post-orogenic characteristics [31,49-51].

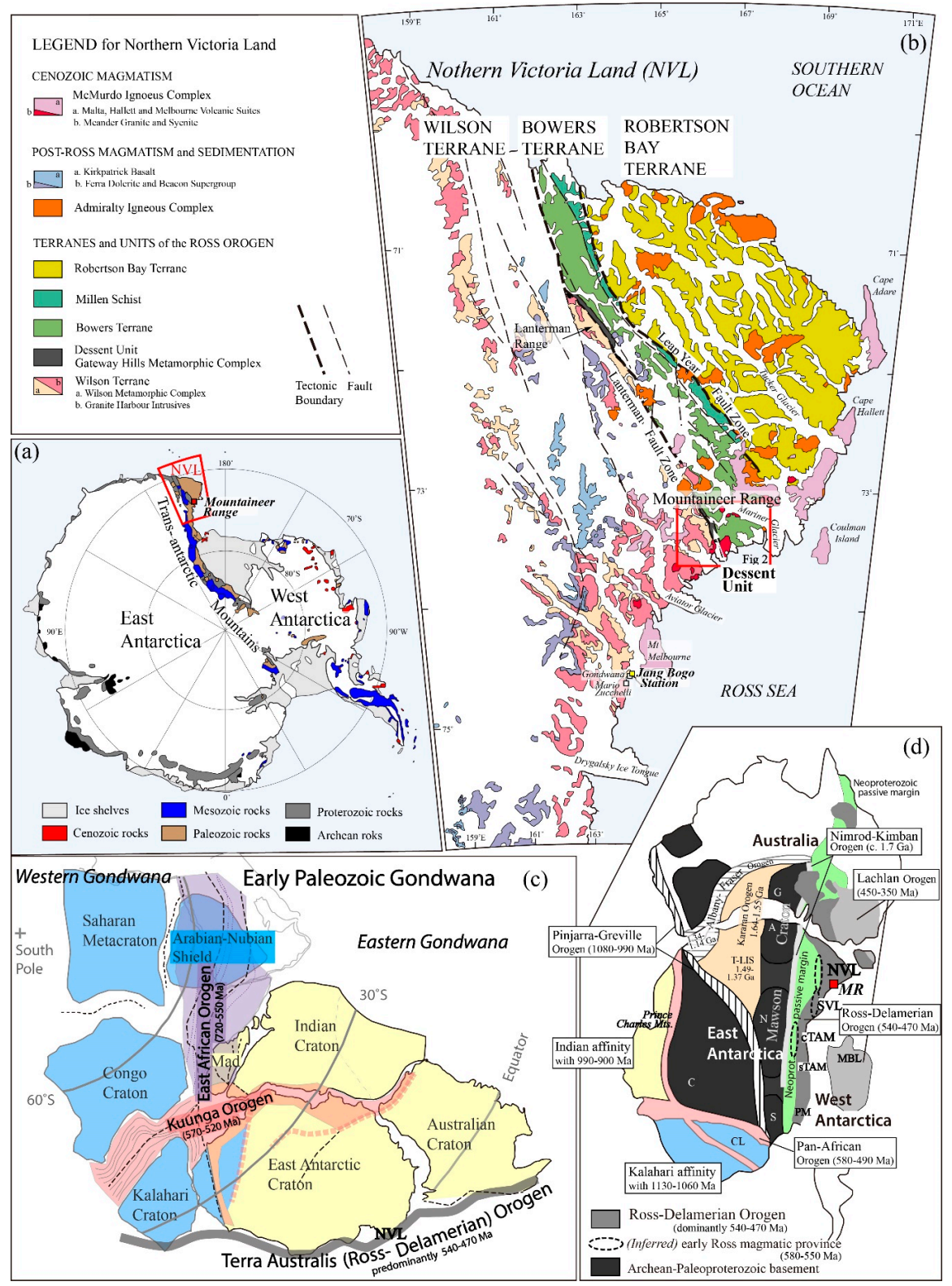

Figure 1. Geological map of Antarctica and Northern Victoria Land (NVL). (a) The simplified geological map of Antarctica with the NVL location (modified after Yi et al. [52]). (b) Geological map of NVL encompassing the Wilson (WT), Bowers (BT) and Robertson Bay terranes (RBT) and showing the study area (Mountaineer Range) (modified after Capponi et al. [43,44]). (c) East Antarctica and surrounding cratons in Gondwana during the early Paleozoic with the Pan-African (East African Orogen and Kuunga Orogen) and Terra Australis (Ross-Delamerian Orogen) belts (modified after Meert [2] and Tosvik and Cocks [6]). (d) Paleogeographic configuration of the Antarctic-Australia Craton during late Cretaceous to early Paleogene period and geological correlation of two cratons (modified after Boger [5], Goodge [26], Estrada et al. [39] and Foster and Goscombe [53]). Abbreviations: A, Terre Adélie Land; cTAM, central Transantarctic Mountains; C, Crohn Craton; CL, Coats Land Block; G, Gawler Craton; MR, Mountaineer Range; N, Nimrod Complex; PM, Pensacola Mountains; S, Shackelton Range; sTAM, southern Transantarctic Mountains; SVL, southern Victoria Land; T-LIS, Trans-Laurentian Igneous Suite. 
The BT comprises volcano-sedimentary sequences developed in the NW-SE direction between the Lanterman Fault and the Leap Year Fault. From bottom to top, the BT consists of the Sledgers Group (submarine volcanics and sediments), Mariner Group (shallow marine sediments) and Leap Year Group (deltaic to fluvial sediments), all of which underwent a low-grade metamorphism [36,45]. The Black Spider Greenschist (BSG), which is composed of metapelites, metaconglomerates and metavolcanics, zone developed in the BT margin towards the WT $[45,54,55]$. The formation age of this volcano-sedimentary group is estimated to be middle to late Cambrian [36,39]. This study's field research identifies schist/phyllite and various (meta)igneous rocks, including diabase, granite porphyry and granodiorite, which were deformed in the greenschist facies metamorphic condition. The Cambrian to early Ordovician RBT consists of thick, folded, monotonous turbidite deposits consisting of greywackes and mudstones. (Meta)sedimentary rocks of the RBT exhibit a very low metamorphic grade that increases marginally towards the BT [56].

High-strain metamorphic rocks characterize the terrane boundaries. Metamorphic mafic rocks comprise the WT/BT boundary (Lanterman Fault zone). While deformed eclogite, amphibolite and ultramafic rocks have been reported in the Lanterman Range, the Dessent Unit of the Mountaineer Range comprises mylonitic amphibolite and metasedimentary rocks. Both metamafic rocks occur as lenses or tectonic slices [33,34,57-61]. The metamorphic P-T conditions and ages of the Lantermann eclogite were reported as 22-25 kbar (630-650 $\left.{ }^{\circ} \mathrm{C} ; 515 \pm 4 \mathrm{Ma}\right)$ and $26 \pm 4 \mathrm{kbar}$ $\left(720 \pm 30^{\circ} \mathrm{C} ; 498 \pm 11 \mathrm{Ma}\right)$ [61]. In the Dessent Unit, medium-P metamorphic conditions were suggested, and peak metamorphic conditions were $9 \mathrm{kbar}\left(690^{\circ} \mathrm{C}\right.$ : [59]) and $5-7 \mathrm{kbar}\left(700-750{ }^{\circ} \mathrm{C}\right.$ : [62]), differing between each location. The age and metamorphic P-T conditions of the Dessent Unit amphibolites are discussed in depth in this study. The tectonic boundary between the BT and the RBT is characterized by the sheared Millen Schist Belt [47]. This metamorphic belt consists of the strongly deformed lower Robertson Bay Group-like metasedimentary unit and upper Sledgers Group (BT)-like metavolcano-sedimentary unit $[33,55,63]$. Their deformational (i.e., metamorphic) age is reported as 462 Ma for syndeformational white mica [64].

\section{Field Occurrence and Relationship}

This study presents the results of research activities in the Mountaineer Range that comprises Mt. Murchison (WT margin), the Dessent Unit (tectonic slice) and the BSG zone (BT margin), all of which correspond to the areas around the WT/BT boundary, as well as the Tiger Gabbro Complex (TGC) (Figure 2). Moreover, the aspects of the Cambro-Ordovician Ross Orogeny in the Mountaineer Range are discussed.

The Mt. Murchison region is located on the WT's eastern margin and is mainly composed of gneisses and granites. The gneisses occur as migmatitic gneiss and sub-magmatic migmatite that consists primarily of leucosome, and in some areas, hornblende gneisses are observed. The dominant rock type is migmatitic gneiss, which shows at least two deformation stages $\left(D_{1}\right.$ and $\left.D_{2}\right)$. Moreover, the migmatitic gneiss underwent two stages of migmatization (i.e., partial melting; Figure 3a). The migmatitic gneiss underwent regional, dynamothermal metamorphism, including the $\mathrm{D}_{1}$ gneiss formation stage, partial melting (migmatitic gneiss formation), folding $\left(\mathrm{D}_{2}\right)$ and second stage partial melting, and, finally, was intruded by granites. Gneissosity, including leucosome of the migmatitic gneiss, was transformed into an isoclinal recumbent fold. Several fold structure components appear to be destroyed by the second stage of migmatization, indicating that a regional compressive force deformed the Mt. Murchison region during granulite facies metamorphism (Figure 3a). The strike of the fold axial plane of the recumbent fold is dominantly (sub)parallel to that of the Lanterman Fault, with the NW-SE direction gently dipping towards the SW, indicating that the Mt. Murchison area and the adjacent area were under a regional compression in the NE-SW direction during the Ross Orogeny. As the migmatitic gneiss (SBM173 including leucosome) shows a metamorphic age of 498.3 $\pm 3.4 \mathrm{Ma}$ (U-Pb zircon age of this study), the peak metamorphic and migmatization ages of the Mt. Murchison area can be inferred to be c. $500 \mathrm{Ma}$. In addition, the c. $500 \mathrm{Ma}$ thermal event indicates post- 
or pre- $\mathrm{D}_{2}$ migmatization. The GHI (granite and granodiorite) related to the Ross Orogeny has been reported at Mt. Murchison and its western region [46]. Several types of granites crosscut the gneissosity of the Mt. Murchison gneiss at right angles, suggesting that they are post-Ross orogenic intrusions.

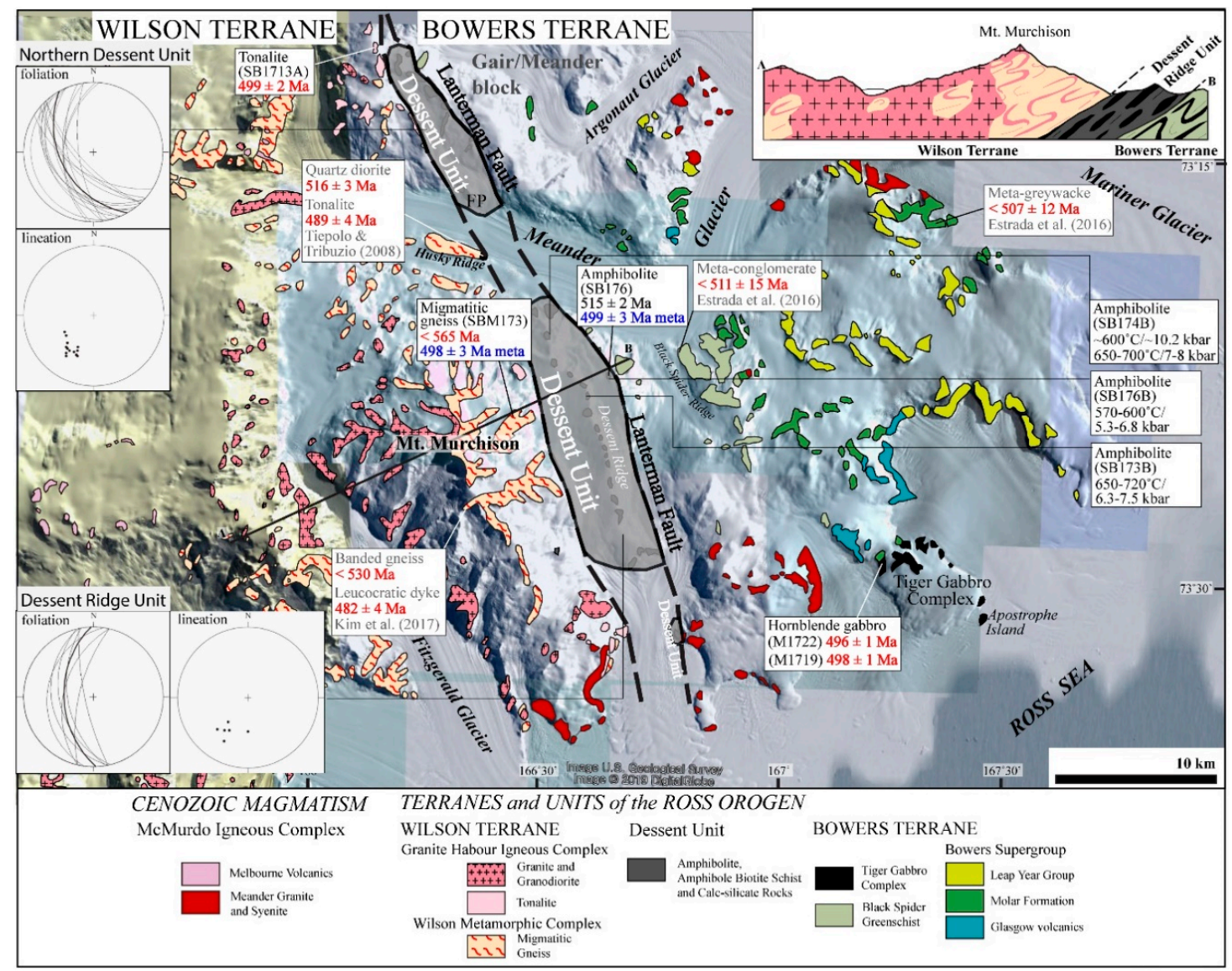

Figure 2. Geological map of the Mountaineer Range (modified after Capponi et al. [43,44]) with zircon $\mathrm{U}-\mathrm{Pb}$ ages. The profile (A-B) structure crosscutting Mt. Murchison was adopted and modified from Capponi et al. $[43,44]$. The Mountaineer Range is located in the WT/BT boundary region and includes Mt. Murchison (WT), the Tonalite Belt (WT), the Dessent Unit, the Black Spider Greenschist (BT), the Tiger Gabbro Complex (TGC) and the Bowers Supergroup (BT). The Lanterman Fault zone borders the WT and the BT. Structural measurements (mylonitic foliation and mineral stretching lineation) and metamorphic $\mathrm{P}$ (pressure)-T (temperature) conditions of the Dessent Unit are presented. For the zircon $\mathrm{U}-\mathrm{Pb}$ ages, igneous and protolith ages are marked in red and metamorphic ages in blue. Literature zircon $\mathrm{U}-\mathrm{Pb}$ data include those of Estrada et al. [39], Kim et al. [48] and Tiepolo and Tribuzio [65]. FP, Frank Point.

The NW-SE-trending Tonalite Belt developed between the Mt. Murchison gneisses and the Dessent Unit (Figure 2). Tonalitic rocks in this belt are predominantly foliated, occur on the west side of the Lanterman Fault zone and are assigned to the GHI [33,34,44]. The age-dated tonalite in this study is weakly sheared (N-S strike; Figure 3b), with an intrusion age of $499.3 \pm 2.1 \mathrm{Ma}$ (U-Pb zircon), consistent with the metamorphic age of the Mt. Murchison migmatitic gneiss and also similar to the igneous age of gabbroic pegmatite in the TGC (see Section 5). This suggests that a distinct tonalitic to gabbroic intrusion occurred in the WT/BT boundary and its adjacent area c. $500 \mathrm{Ma}$ ago, causing anatexis and peak metamorphism in the Mt. Murchison region. The mylonitic foliation in the tonalites indicates that crystal-plastic deformation continued in the Lantermann Fault zone after peak metamorphism (c. $500 \mathrm{Ma}$ ). 

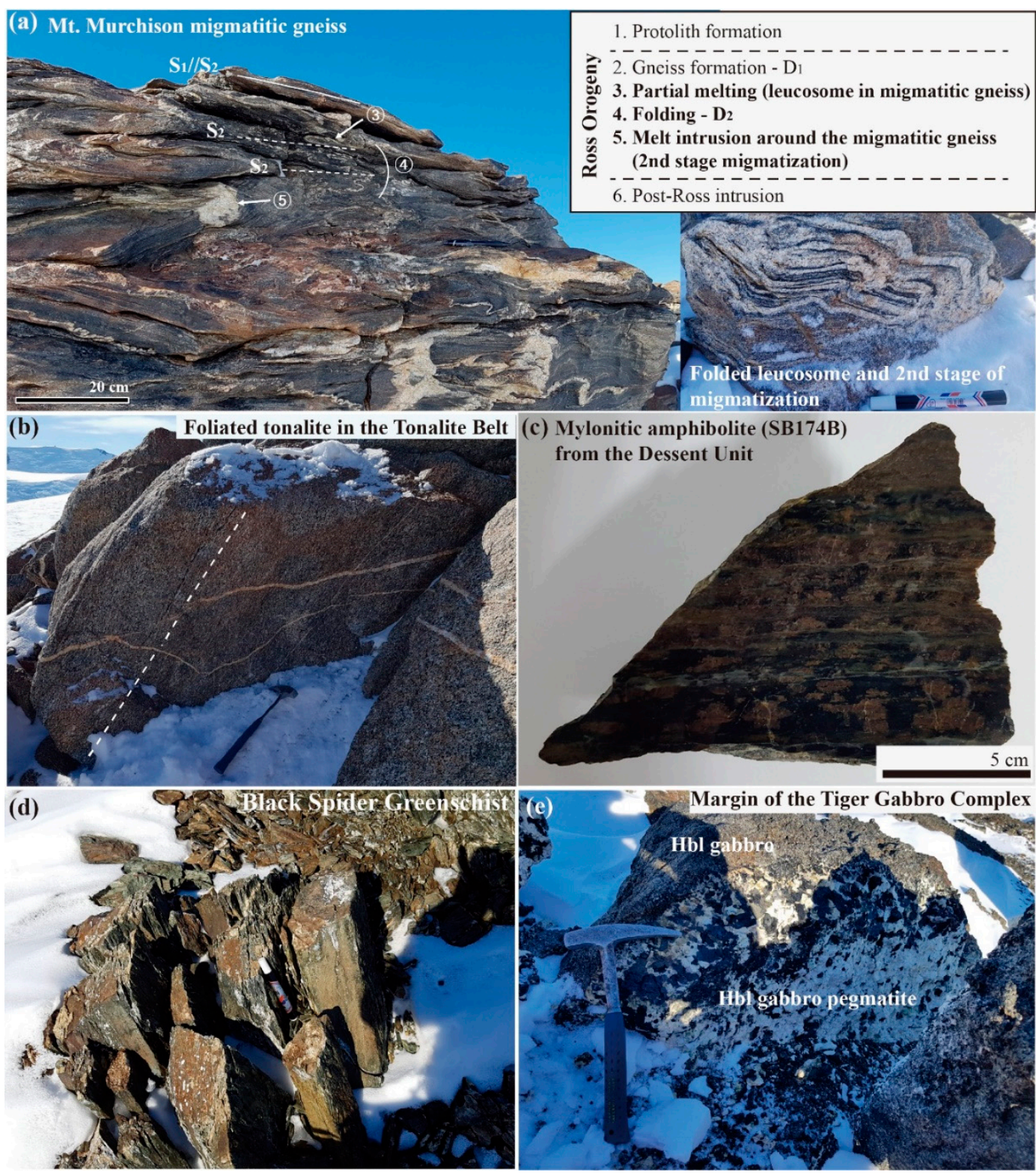

Figure 3. Field observation in the Mountaineer Range. (a) Migmatitic gneisses and field summary for the Mt. Murchison metamorphic stage: The $S_{1}$ foliation $\left(D_{1}\right.$-related) was deformed and merged into the $S_{2}\left(D_{2}\right.$-related) fold axial plane (\#2-4 in the inset). Second stage migmatization destructed a folded leucosome (first stage migmatization) (right small figure and \#5 in the inset). (b) Foliated tonalite from the Tonalite Belt. (c) Hand specimen of mylonitic amphibolite (SB174B) collected from the Dessent Unit. (d) Black Spider Greenschist (BSG) with mineral stretching lineation plunging to the SW. (e) Hornblende (hbl) gabbro and hbl gabbro pegmatite developed in the margin of the TGC.

The Dessent Unit is characterized by mylonitic rock bodies that developed between the WT and the BT and consists of the Dessent Ridge unit in the south of the Meander Glacier and the northern unit between the Gair Glacier and the Meander Glacier (Gair/Meander block). The Dessent Unit is visible as elongated bodies trending NW-SE. The bodies are in contact with the Tonalite Belt/Mt. Murchison gneiss (WT) to the west and the BSG (BT) to the east (Figure 2). This unit is considered a tectonic slice with different characteristics from both the Wilson and Bowers terrane lithologies $[33,34,43,44,59]$. The Dessent Unit is represented by a predominant amphibolite lithology with amphibole biotite schist, mafic granulites, quartzite, marble/calcsilicate rocks, metapelites and metaconglomerates, depending on the location (this study) $[33,43,44,62,66,67]$. This unit distinctly retains amphibolite 
facies mineral assemblage, such as hornblende + garnet + plagioclase, with overprints of retrograde minerals (greenschist facies), such as chlorite + epidote + muscovite. The occurrence of retrograde greenschist facies mineral assemblage is pronounced in the northern unit (within the Gair/Meander block). In Frank Point, north of the Meander Glacier, granulite facies metamorphism (clinopyroxene + garnet + plagioclase) is preserved [62]. Most of the Dessent Unit amphibolites were mylonitized, and the retrogressed (greenschist facies) samples predominantly retain $\mathrm{S}-\mathrm{C}$ fabric and extensional crenulation cleavage (ECC) (Figure 4a). Several amphibolites are characterized by alternate hornblendeand garnet-rich layers. The hornblendes are typically strongly aligned or form fine-grained aggregates, while the garnets appear in elongated bands (Figures $3 c$ and $4 b$ ). Mylonitic foliations developed parallel (NW-SE strike) or subparallel (N-S strike) to the Lanterman Fault that is considered to be a tectonic boundary. Mineral stretching lineations generally plunge towards $220-230^{\circ}$ directions, which are slightly oblique to the down-dip direction of mylonitic foliations (Figure 2). Macroscopic folds are identified locally and their fold axial plane is generally subparallel to the regional mylonitic foliation.

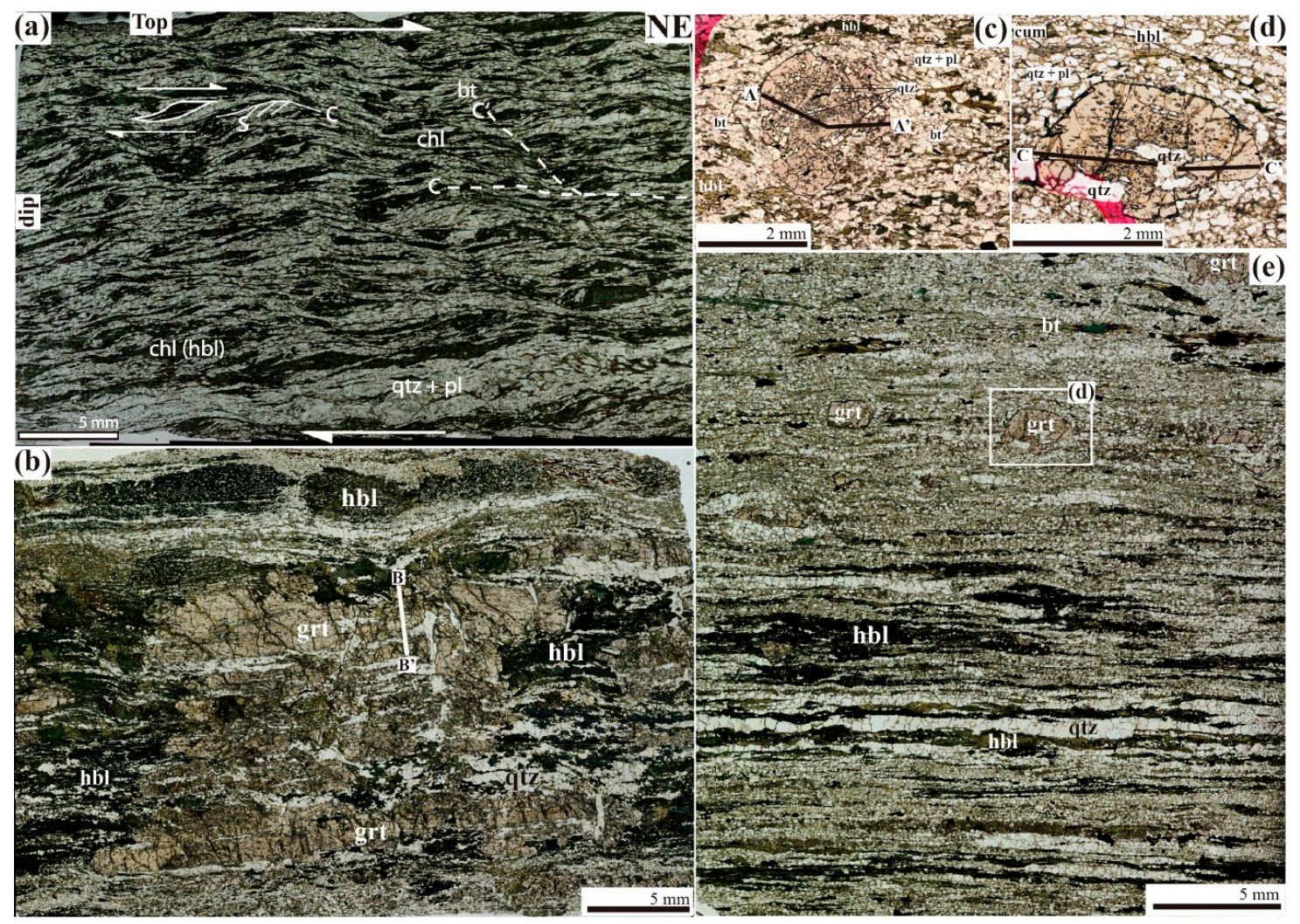

Figure 4. Microphotographs of mylonitic amphibolites from the Dessent Unit: (a) Retrogressed amphibolite (SB175A) with S-C-C' fabric and chlorite (chl) fish: $\mathrm{C}^{\prime}$ denotes extensional crenulation cleavage (ECC). Chlorite pseudomorphs after hornblende (chl (hbl)) are common here. (b) Amphibolite (SB174B) showing an elongated garnet (grt) band and hornblende (hbl) stretching lineation: some parts (top layer) of hornblende form aggregates of fine-grains, possibly due to dissolution-precipitation. (c,d) Garnet porphyroblasts in amphibolites ((c) SB173B and (d) SB176B) with associated minerals). (e) Amphibolite (SB176B) showing distinct dynamic recrystallization textures: recrystallized quartz (qtz) forms an elongated band or a polygonal granoblastic fabric, and hornblende exhibits strong stretching lineation. Garnet profiles $\left(\mathrm{A}-\mathrm{A}^{\prime}, \mathrm{B}-\mathrm{B}^{\prime}\right.$ and $\left.\mathrm{C}-\mathrm{C}^{\prime}\right)$ shown in Figure 8 are presented in (c), (b) and (d), respectively. Photos were taken under a plane-polarized light. Abbreviations: bt, biotite; cum, cummingtonite; pl, plagioclase.

To the east of the Dessent Unit, the BSG crops out, occurring as narrow and elongated rock bodies trending NW-SE parallel to the Dessent Unit. The BSG corresponds to the western margin 
of the BT $[33,43,44,55,68]$. In this schist zone, greenschist/phyllite and metadiabase (hornblende gabbro precursor) alternate repetitively and have a deformation structure along with (meta)granite porphyry/(meta)granodiorite. The greenschist/phyllite shows a predominant mylonitic texture, whereas a distinct, dynamic recrystallization texture is absent in the meta-igneous rocks, which display a metasomatic overprint of secondary minerals (chlorite + epidote). All the BSG rocks appear to have undergone greenschist facies metamorphism and have been deformed into tight to isoclinal folds and partially mylonitized. Their fold axial planes are sub-parallel to the Dessent Unit's mylonitic foliation.

The TGC is located in the easternmost part (southeast) of the study area and within the BT. This complex consists of cumulative mafic-ultramafic igneous rocks, such as various gabbroic rocks, anorthosites, pyroxenites and hornblendites, which generally crop out as undeformed and unmetamorphosed. A narrow ( 10 cm width) local shear zone has been identified on Apostrophe Island (this study) [69,70]. The relationship between the TGC and the BT metasedimentary rock is interpreted as either an intrusive contact [70,71] or a shear contact [33]. Based on this study's field survey, the TGC's cumulate piles were intruded by hornblende gabbro and hornblende gabbro pegmatite at the Complex margin. U-Pb zircon dating indicates a hornblende gabbro pegmatite (i.e., frozen melt) intrusion age of c. $497 \mathrm{Ma}$ (this study). The outcrop arrangement of the hornblende gabbro (pegmatite) intrusive bodies shows an E-W trend and differs from the strikes (NW-SE) of the TGC's dominant igneous bedding. This suggests that the boundary between the TGC's main body and the BT metasedimentary rock is obscured by the late intrusive nature of hornblende gabbro pegmatite. Furthermore, it indicates that the formation age of the complex's cumulate piles exceeds $\mathrm{c}$. $497 \mathrm{Ma}$. A coarse-grained gabbro sample from the TGC cumulates, which hosts the Ediacaran-age zircons as well as the Paleoproterozoic to Neoarchean xenocrystic zircons, has been reported [72]. A geochronological comparison between the age of the Tiger Gabbro cumulates and the hornblende gabbro pegmatite and the number of different chronological units comprising the igneous complex has not yet been established.

\section{Analytical Methods}

For zircon $\mathrm{U}-\mathrm{Pb}$ age dating, five metamorphic and igneous rocks were crushed for conventional density and magnetic separations. Zircons were separated from the selected heavy minerals using tweezers and were then mounted using epoxy along with standard zircons. Zircon cathodoluminescence (CL) and back scattered electron (BSE) images were obtained using a scanning electron microscope (JEOL 6610LV model) at the Ochang Center of the Korea Basic Science Institute (KBSI), Republic of Korea. We based our analytical zircon $\mathrm{U}-\mathrm{Pb}$ dating procedures on the methods of Williams [73] and Ireland and Williams [74]. The analyses were conducted using SHRIMP IIe at the Ochang Center of the KBSI. A primary ion $\left(\mathrm{O}^{2-}\right)$ beam was used for analyses, and the size and current of the beam were $20-25 \mu \mathrm{m}$ and $4-6 \mathrm{nA}$, respectively. The standard zircon SL13 was used to measure the U concentration [75], and the $\mathrm{U}-\mathrm{Pb}$ isotope ratios were calibrated using the FC1 zircon [76]. Each $\mathrm{U}-\mathrm{Th}-\mathrm{Pb}$ analysis of zircons consisted of five scans throughout the mass range. Ages were calculated using the decay constants of Steiger and Jäger [77]. Data reduction, age calculation and common $\mathrm{Pb}$ correction were performed using SQUID v. 2.5 and Isoplot/Ex 3.41 [78]. The U-Th-Pb isotope ratios and ages of each analysis are at the $1 \sigma$ uncertainty level. The uncertainty levels for the calculated concordia age and the weighted mean age are $1 \sigma$ and $2 \sigma$, respectively.

To determine the major element concentrations of metamorphic rocks, we conducted a whole-rock analysis using an X-ray fluorescence (XRF) spectrometer. Fresh samples were leached in a dilute acid solution and pulverized to $<150$ mesh $(105 \mu \mathrm{m})$ powder in a tungsten carbide mill bowl (Niand $\mathrm{Cr}$-free). Dried sample powders were weighed in a ceramic crucible and ignited in a muffle furnace for $20 \mathrm{~min}$ at $1000{ }^{\circ} \mathrm{C}$. Loss on ignition (LOI) was determined by comparing the weights before and after the ignition. Glass beads were prepared by mixing $0.6 \mathrm{~g}$ of powdered sample and $6.0 \mathrm{~g}$ of the alkali flux (lithium tetraborate, $\mathrm{Li}_{2} \mathrm{~B}_{4} \mathrm{O}_{7}$ ). The mixture was put into a platinum 
crucible ( $5 \%$ gold) with $0.05 \mathrm{~g}$ of exfoliation agent (lithium bromide, Liberia). Fusing and agitation were conducted with an automated high-frequency bead sampler (SPEX, K-2 PRIME) at $300 \mathrm{~s}$ of prefusion (c. $1050^{\circ} \mathrm{C}$ ) and $60 \mathrm{~s}$ of fusion (c. $1080{ }^{\circ} \mathrm{C}$ ). The analysis was performed using a wavelength dispersive XRF spectrometer (Pananalytical Axios Max) at the Korea Polar Research Institute (KOPRI), Incheon, Republic of Korea. The XRF spectrometer was equipped with a Philips $4 \mathrm{~kW}$ Rh anode Super Sharp X-ray tube. Calibration and analysis were automatically performed with a SuperQ software package (v. 5.2B, Malvern Panalytical, Almelo, The Netherlands) attached to the spectrometer. The instrumental drift was corrected by measuring the synthetic monitor samples.

We determined the metamorphic mineral compositions using a JEOL JXA-8530F field emission (FE) electron probe micro-analyzer (EPMA) at the KOPRI. The accelerating voltage, beam current and probe diameter were $15 \mathrm{kV}, 10 \mathrm{nA}$ and $5 \mu \mathrm{m}$, respectively. Count times of the peak and background were $20 \mathrm{~s}$ and $10 \mathrm{~s}$, respectively. Certified natural minerals and synthetic oxides were used as standards, and matrix correction was processed using the conventional PhiRhoZ (PRZ) method.

\section{Zircon U-Pb Geochronology}

We established the tectonic evolution of the Mountaineer Range during the Ross Orogeny by SHRIMP zircon U-Pb dating. Samples of migmatitic gneiss (SBM173) from Mt. Murchison (WT), tonalite (SB1713A) from the Tonalite Belt, amphibolite (SB176) from the Dessent Unit and pegmatitic hornblende gabbros (M1722 and M1719) from the outer part of the TGC (BT) were analyzed. The analytical results are presented in Table S1.

A total of 168 zircon spots were analyzed in the migmatitic gneiss (SBM173). In this sample, various types of anhedral, subhedral and euhedral zircons with lengths of approximately 100-250 $\mu \mathrm{m}$ were identified. The zircons exhibit predominantly oscillatory growth zoning in the CL images, suggesting an igneous origin. The zircon cores reveal Paleoproterozoic to Neoproterozoic ages, indicating that these igneous zircons are detrital and that sample SBM173 is a paragneiss. A number of zircon grains exhibit dark rims in the CL image due to metamorphism and several display metamorphic overgrowth textures. Euhedral, unzoned zircons exhibit a low CL emission and reveal metamorphic ages (Figure 5a). The zircon metamorphic zones show a predominantly low $\mathrm{Th} / \mathrm{U}$ ratio of less than 0.1 , with a lower $\mathrm{Th} / \mathrm{U}$ ratio and a higher $\mathrm{U}$ content than the detrital igneous cores. The $\mathrm{Th} / \mathrm{U}$ ratio of a few metamorphic zones is relatively high, ranging from 0.3 to 0.5 . The metamorphic age of the zircons shows a broad apparent age $\left({ }^{206} \mathrm{~Pb} /{ }^{238} \mathrm{U}\right.$ age), varying from $530 \mathrm{Ma}$ to $460 \mathrm{Ma}$. Among these, a predominant concordant age of $498.3 \pm 3.4 \mathrm{Ma}$ (weighted mean of ${ }^{206} \mathrm{~Pb} /{ }^{238} \mathrm{U}$ age: $n=17$, mean squared weighted deviation $(\mathrm{MSWD})=0.87$ ) possibly indicates the timing of migmatization (Figure $6 \mathrm{a}$ ). The detrital zircon age of the migmatitic gneiss (SBM173) is characterized by the predominant Grenville age of 900-950 Ma and 1000-1100 Ma, with an evident late Neoproterozoic age of 562.4 $\pm 6.0 \mathrm{Ma}$ (weighted mean of ${ }^{206} \mathrm{~Pb} /{ }^{238} \mathrm{U}$ age: $n=11, \mathrm{MSWD}=0.57$ ) as the youngest detrital age. Other detrital ages, such as 600-650 Ma, c. $800 \mathrm{Ma}$, c. $1400 \mathrm{Ma}$, c. $1670 \mathrm{Ma}$, c. $2250 \mathrm{Ma}$ and c. $2450 \mathrm{Ma}$ were also identified (Figure $6 a, b)$. Thus, it can be interpreted as that the protolith of the migmatitic gneiss (SBM173) was formed in the late Neoproterozoic (Ediacaran, c. $560 \mathrm{Ma}$ ) to early Paleozoic (early Cambrian, c. $530 \mathrm{Ma}$ ) and underwent a peak temperature metamorphism (i.e., migmatization) at c. $500 \mathrm{Ma}$. In addition, the dispersion of the metamorphism age from $530 \mathrm{Ma}$ to $460 \mathrm{Ma}$ indicates that metamorphism continued before and after $500 \mathrm{Ma}$. Several metamorphic zircons have a discordant age shifting towards the Mesozoic era, indicating that the migmatitic gneiss (SBM173) underwent a Mesozoic thermal event after the Ross Orogeny (Figure 6a).

Twenty-eight zircon spots were analyzed in the deformed tonalite (SB1713A). In the sample, euhedral zircons, with a length of 100-200 $\mu \mathrm{m}$, exhibit oscillatory growth zoning in the CL images (Figure 5b). Neither an inherited core nor an apparent metamorphic rim was observed in these zircons. The zircon $\mathrm{Th} / \mathrm{U}$ ratios range from 0.13 to 0.95 . The apparent ${ }^{206} \mathrm{~Pb} /{ }^{238} \mathrm{U}$ ages are distributed between $507 \mathrm{Ma}$ and $481 \mathrm{Ma}$, and the weighted mean of ${ }^{206} \mathrm{~Pb} /{ }^{238} \mathrm{U}$ age for 23 concordant spots is $499.3 \pm 2.1 \mathrm{Ma}$ $(\mathrm{MSWD}=0.75)$ corresponding to the intrusion age of the tonalite (SB1713A). Three younger concordant 
spots reveal a ${ }^{206} \mathrm{~Pb} /{ }^{238} \mathrm{U}$ age of $481-484 \mathrm{Ma}( \pm 4$ or $5 \mathrm{Ma})$, possibly suggesting a younger igneous event (Figure 6c).

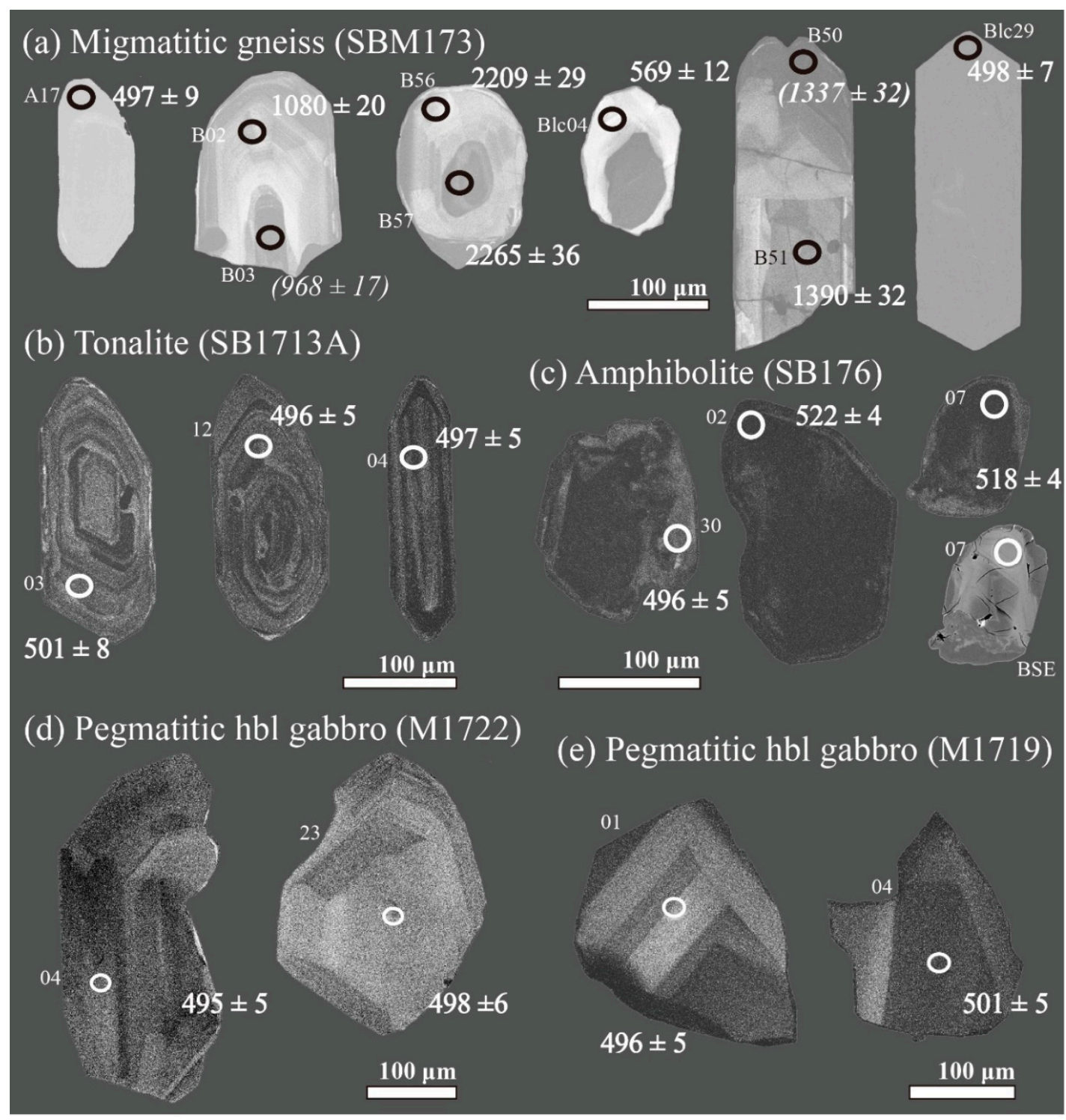

Figure 5. Representative cathodoluminescence (CL) images of zircon and the spots of the SHRIMP $\mathrm{U}-\mathrm{Pb}$ analyses with ${ }^{206} \mathrm{~Pb} /{ }^{238} \mathrm{U}$ ages (Ma) (discordant ages denoted in italics) of (a) migmatitic gneiss (SBM173; Mt. Murchison, WT), (b) tonalite (SB1713A; Tonalite Belt), (c) amphibolite (SB176; Dessent Unit), (d) pegmatitic hornblende (hbl) gabbro (M1722; TGC, BT) and (e) pegmatitic hbl gabbro (M1719; TGC, BT). The Paleoproterozoic ages (2209 Ma and 2265 Ma) of the migmatitic gneiss (SBM173) (a) are ${ }^{207} \mathrm{~Pb} /{ }^{206} \mathrm{~Pb}$ ages. The small-sized numbers are the spot numbers in Table S1. One backscattered electron (BSE) image of the amphibolite (SB176) (c) is compared with its CL image. 

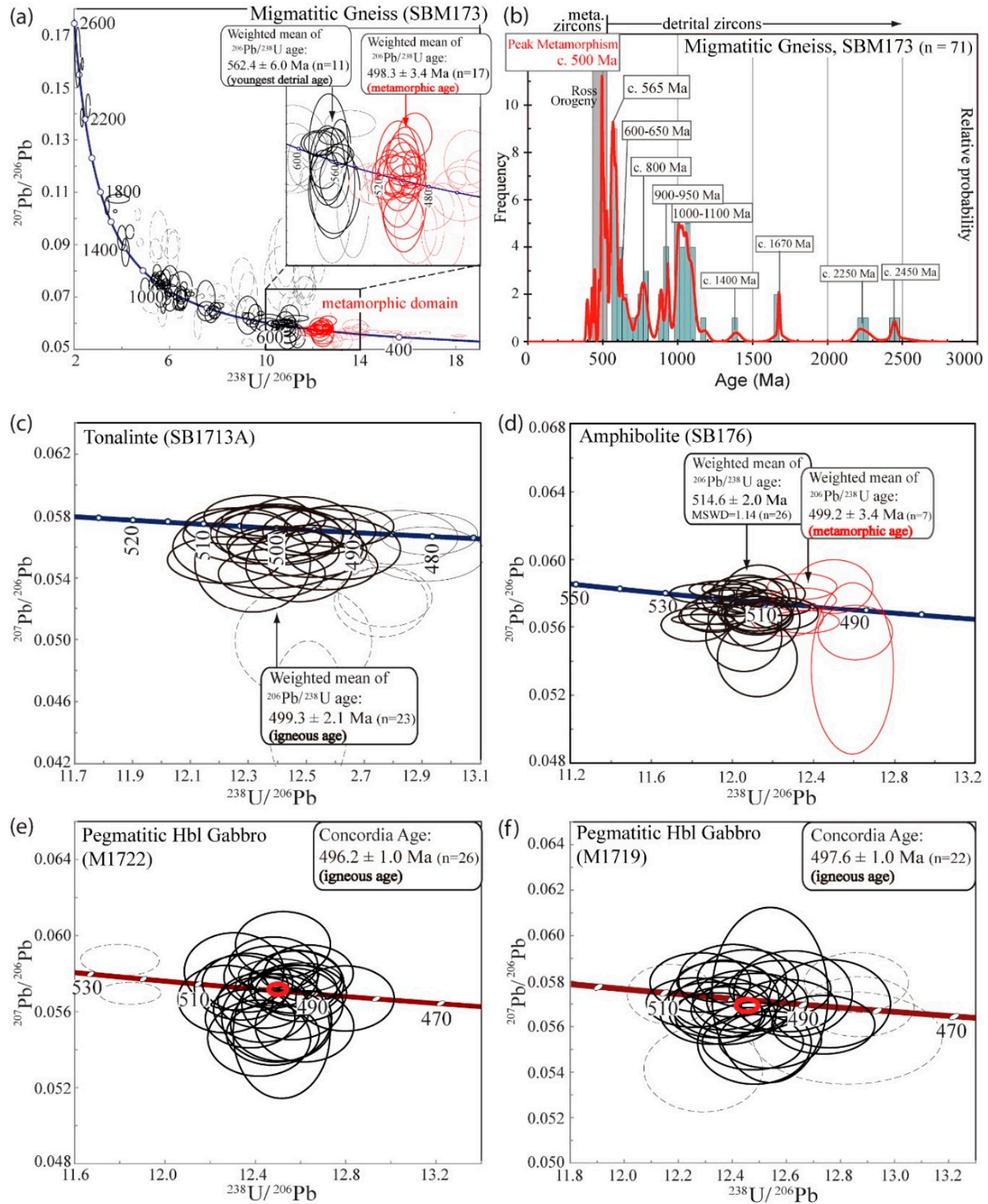

Figure 6. Tera-Wasserburg concordia diagrams showing the SHRIMP spot dates of zircon from the Mountaineer Range. (a) Result for the migmatitic gneiss (SBM173) from Mt. Murchison (WT), (b) the relative probability distribution-frequency histogram of detrital zircons and metamorphic zircons with a concordance of $>90 \%\left({ }^{206} \mathrm{~Pb} /{ }^{238} \mathrm{U}\right.$ ages for $<1500 \mathrm{Ma}$ and ${ }^{206} \mathrm{~Pb} /{ }^{238} \mathrm{U}$ ages for $>1500$ Ma) from the migmatitic gneiss (SBM173), (c) results for the tonalite (SB1713A) from the Tonalite Belt, (d) the amphibolite (SB176) from the Dessent Unit and (e,f) pegmatitic hornblende ( $\mathrm{Hbl}$ ) gabbros from the northwestern margin of the TGC (BT).

Thirty-two zircon spots were analyzed in the Dessent Unit amphibolite sample (SB176). The anhedral and subhedral zircons were approximately $100 \mu \mathrm{m}$ long and hosted inclusions of biotite, garnet, plagioclase and iron oxide. Although the core and rim of the zircons are not distinguishable due to their unzoned and low CL emissions, these are relatively distinct in the BSE image (Figure 5c). The zircon Th/U ratios range from 0.64 to 3.05 and, except for one spot (spot no. 30: rim position, 
$\mathrm{Th} / \mathrm{U}=0.01$ ), showed no core-rim position distinction. The dominant age of the zircon core and rim is calculated as $514.6 \pm 2.0 \mathrm{Ma}$ (weighted mean of ${ }^{206} \mathrm{~Pb} /{ }^{238} \mathrm{U}$ age: $n=26$, MSWD $=1.14$ ). Several spots in the zircon rim reveal a younger age of $499.2 \pm 3.4 \mathrm{Ma}$ (weighted mean of ${ }^{206} \mathrm{~Pb} /{ }^{238} \mathrm{U}$ age: $n=7$, MSWD = 1.2), corresponding to the metamorphic age of the amphibolite sample (SB176) (Figure 6d). The presence of garnet inclusions and the migmatitic gneiss's metamorphic age range suggest that the dominant age obtained for the zircon core and rim (514.6 $\pm 2.0 \mathrm{Ma})$ indicates the metamorphic age of the amphibolite (SB176). Thus, the amphibolite (SB176) ages (514.6 $\pm 2.0 \mathrm{Ma}$ and 499.2 $\pm 2.0 \mathrm{Ma}$ ) are presumed to indicate the ages of the first and second metamorphic stages.

It is estimated that pegmatitic hornblende gabbros (M1722 and M1719) intrude the boundary between the TGC and BT metasedimentary rock. Zircons of sample M1722 are dominated by euhedral grains with lengths of $200-400 \mu \mathrm{m}$. They all show oscillatory growth zoning in the CL image and do not have an inherited core (Figure $5 \mathrm{~d}$ ). Twenty-eight spots were analyzed for these zircons. Th/U ratios of the analyzed zircons range from 0.16 to 0.76 , except for one spot (spot no. $16, \mathrm{Th} / \mathrm{U}=0.01$ ). Analytical spots yield a concordia age of $496.2 \pm 1.0 \mathrm{Ma}(n=26, \mathrm{MSWD}=0.2)$ in the Tera-Wasserburg diagram, which corresponds to the intrusion age of the hornblende gabbro (M1722) (Figure 6e). The zircons of sample M1719 are similar to those of sample M1722 based on their morphology and internal structure. These are euhedral grains with a length of $200-400 \mu \mathrm{m}$, all showing oscillatory growth zoning without inheritance (Figure $5 \mathrm{e}$ ). Their Th/U ratios are in the range of $0.31-0.79$. Twenty-seven spots were analyzed for these zircons. In the Tera-Wasserburg diagram, 22 spots with high concordance yield a concordia age of $497.6 \pm 1.0 \mathrm{Ma}(\mathrm{MSWD}=1.3)$, which corresponds to the intrusion age of the hornblende gabbro (M1719) (Figure 6f). Pegmatitic hornblende gabbros (M1722 and M1719) show the same igneous age, approximately $497 \mathrm{Ma}$.

In summary, the WT and BT's primary lithologies developed around the Dessent Unit are highlighted by the intrusion of mafic to intermediate igneous rocks and associated migmatization around $500 \mathrm{Ma}$. This corresponds to the Ross Orogeny's prominent thermal peak in the Mountaineer Range, which occurred between $520 \mathrm{Ma}$ and $480 \mathrm{Ma}$.

\section{Metamorphic P-T Estimation}

For the metamorphic P (pressure)-T (temperature) estimation of the Ross Orogeny, pseudosection analysis and conventional geothermobarometers were applied to amphibolites from the Dessent Unit. Based on whole-rock geochemistry, the amphibolites are basaltic andesite to dacite in composition, with a prominent tholeiite affinity. The $\mathrm{P}-\mathrm{T}$ pseudosections for three samples (SB173B, SB174B and SB176B) were calculated in the $\mathrm{MnO}-\mathrm{Na}_{2} \mathrm{O}-\mathrm{CaO}-\mathrm{K}_{2} \mathrm{O}-\mathrm{FeO}-\mathrm{MgO}-\mathrm{Al}_{2} \mathrm{O}_{3}-\mathrm{SiO}_{2}-\mathrm{TiO}_{2}-\mathrm{H}_{2} \mathrm{O}$ (MnNCKFMASHT) system using the PERPLE_X program (http://www.perplex.eths.ch/) [79] with an internally consistent thermodynamic dataset [80] (updated in 2002). The following solid solution models (the downloaded version of the solution model file) were used to calculate the pseudosection: $\mathrm{Pl}(\mathrm{h})$ for plagioclase (pl) [81], $\mathrm{Gt}(\mathrm{HP})$ for garnet (grt) [80], TiBio for biotite (bt) [82,83], Mica(CHA) for muscovite or potassic white mica (ms) [84,85], hCrd for cordierite (crd; ideal mixing model), Opx(HP) for orthopyroxene (opx) [86], $\mathrm{Cpx}(\mathrm{HP})$ for clinopyroxene (cpx) [86], Chl(HP) for chlorite (chl) [87], Amph(DPW) for clinoamphibole (amp) [88] and melt(HP) for silicate melt [89,90]. $\mathrm{A}_{2} \mathrm{O}$ content of $1.5 \mathrm{wt}$. \% was applied collectively to the calculations of the three samples. The equilibrium mineral assemblage and the calculated compositional isopleths for garnet were used to confirm the peak metamorphic condition in the pseudosection. Because biotite, hornblende and plagioclase mostly appear in the matrix with garnet, the garnet-biotite geothermometer (GB) [91], garnet-hornblende geothermometer (GH) [92,93], garnet-biotite-plagioclase-quartz geobarometer (GBPQ) [94] and garnet-hornblende-plagioclase-quartz geobarometer (GHPQ) $[95,96]$ were applied with garnet rim composition. Major mineral compositions and the $\mathrm{P}-\mathrm{T}$ conditions estimated by using conventional geothermobarometry and garnet profile compositions are presented in Tables S2 and S3, respectively. 


\subsection{Amphibolite (SB173B) from the Dessent Unit}

Sample SB173B is a mylonitic amphibolite (Figure 4c) and is geochemically equivalent to andesite. Pseudosection modeling of the amphibolite (SB173B) in a pressure range of 1-12 kbar reveals a clinoamphibole stability temperature lower than $\sim 760{ }^{\circ} \mathrm{C}$ and a solidus (melt-in) temperature of $\sim 700{ }^{\circ} \mathrm{C}$. The thermal peak assemblage of the amphibolite (SB173B) is hornblende + plagioclase + garnet + biotite + quartz + ilmenite \pm melt, which is stable at a P-T range of $630-710^{\circ} \mathrm{C}$ and $6.0-9.5 \mathrm{kbar}$ (Figure 7a). The compositional isopleths of garnet were applied to specify metamorphic $\mathrm{P}-\mathrm{T}$ conditions. Garnet porphyroblasts are almandine-rich $\left(X_{\mathrm{alm}}=0.65-0.73\right)$ and spessartine-poor $\left(\mathrm{X}_{\mathrm{sps}}=0.02-0.06\right)$. The core of the garnet porphyroblast has $\mathrm{X}_{\text {pyp }}$ values of $\sim 0.16$ and $\mathrm{X}_{\text {grs }}$ values of $\sim 0.13$, showing a slight, rim-ward compositional increase in $X_{\text {pyp }}(\sim 0.20)$ and a rim-ward decrease in $X_{\text {grs }}(\sim 0.07)$ (Figure 8a). The modeled metamorphic $\mathrm{P}-\mathrm{T}$ conditions of the porphyroblastic garnet core and rim correspond to $610-630{ }^{\circ} \mathrm{C}(\sim 6 \mathrm{kbar})$ and $\sim 630^{\circ} \mathrm{C}(\sim 5 \mathrm{kbar})$, respectively, which are slightly lower than the $\mathrm{P}-\mathrm{T}$ range inferred from the phase assemblage. However, GB and GBPQ geothermobarometry calculation of the pyrope-rich garnet rim reveals $\mathrm{P}-\mathrm{T}$ conditions consistent with the low-pressure limit $\left(650-720^{\circ} \mathrm{C}\right.$ and 6.3-7.5 kbar) of the stable P-T range of main mineral assemblage. This is considered to be a thermal peak metamorphic condition of the amphibolite (SB173B). The three lowered P-T conditions identified by $\mathrm{GB} / \mathrm{GBPQ}$ and $\mathrm{GH} / \mathrm{GHPQ}$ geothermobarometry calculations probably indicate a retrograde process (Figure $7 \mathrm{~b}$ ).

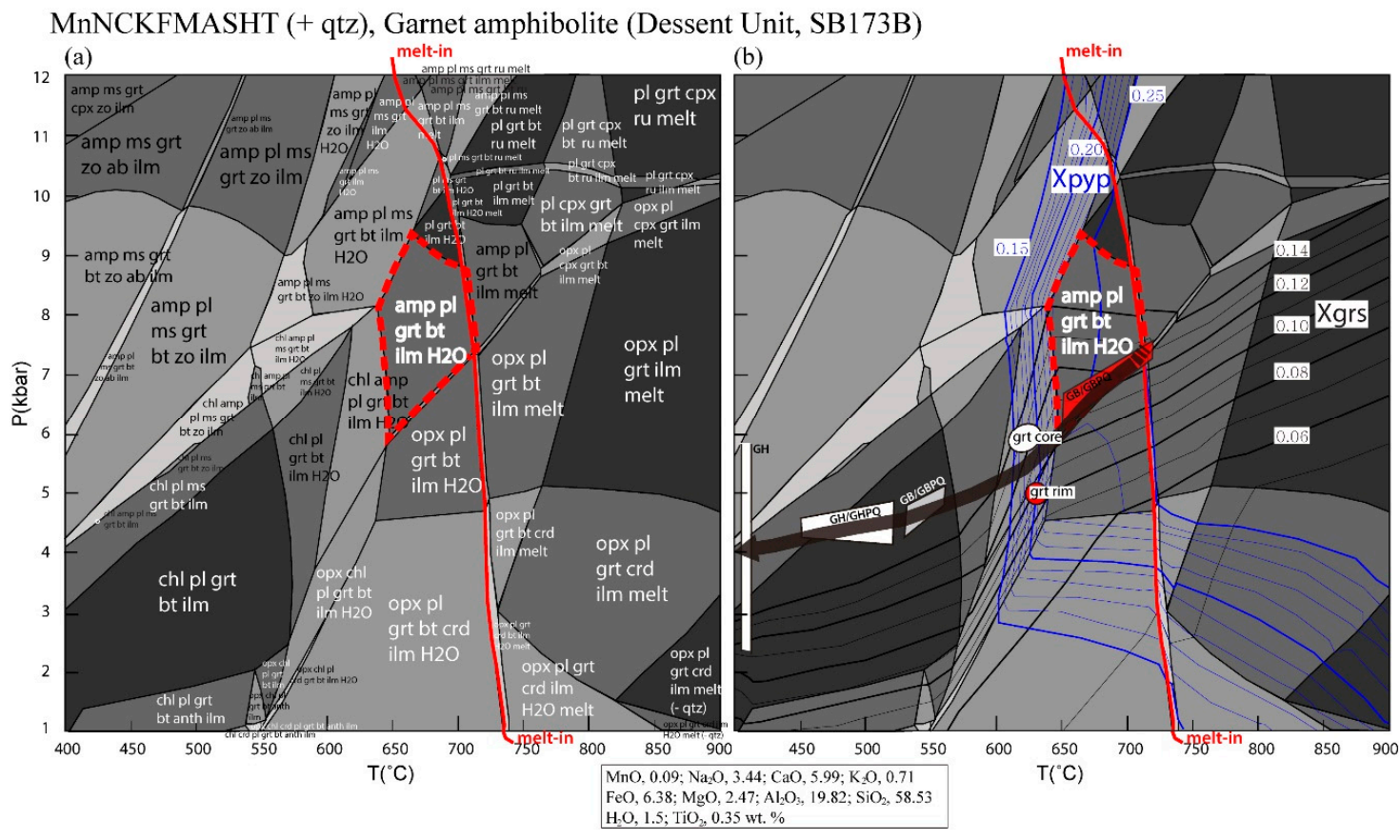

Figure 7. (a) P-T pseudosection for the amphibolite (SB173B) in the MnNCKFMASHT system. (b) P-T pseudosection with compositional isopleths of garnet (grt) porphyroblast for pyrope (pyp) and grossular (grs). The P-T path was identified by the garnet-biotite/garnet-biotite-plagioclase-quartz (GB/GBPQ) geothermobarometry, garnet isopleths and garnet-hornblende/garnet-hornblende-plagioclase-quartz (GH/GHPQ) geothermobarometry. Mineral abbreviations: ab, albite; anth, anthophyllite; ilm, ilmenite; ru, rutile; zo, zoisite. Other abbreviations are explained in the text. 

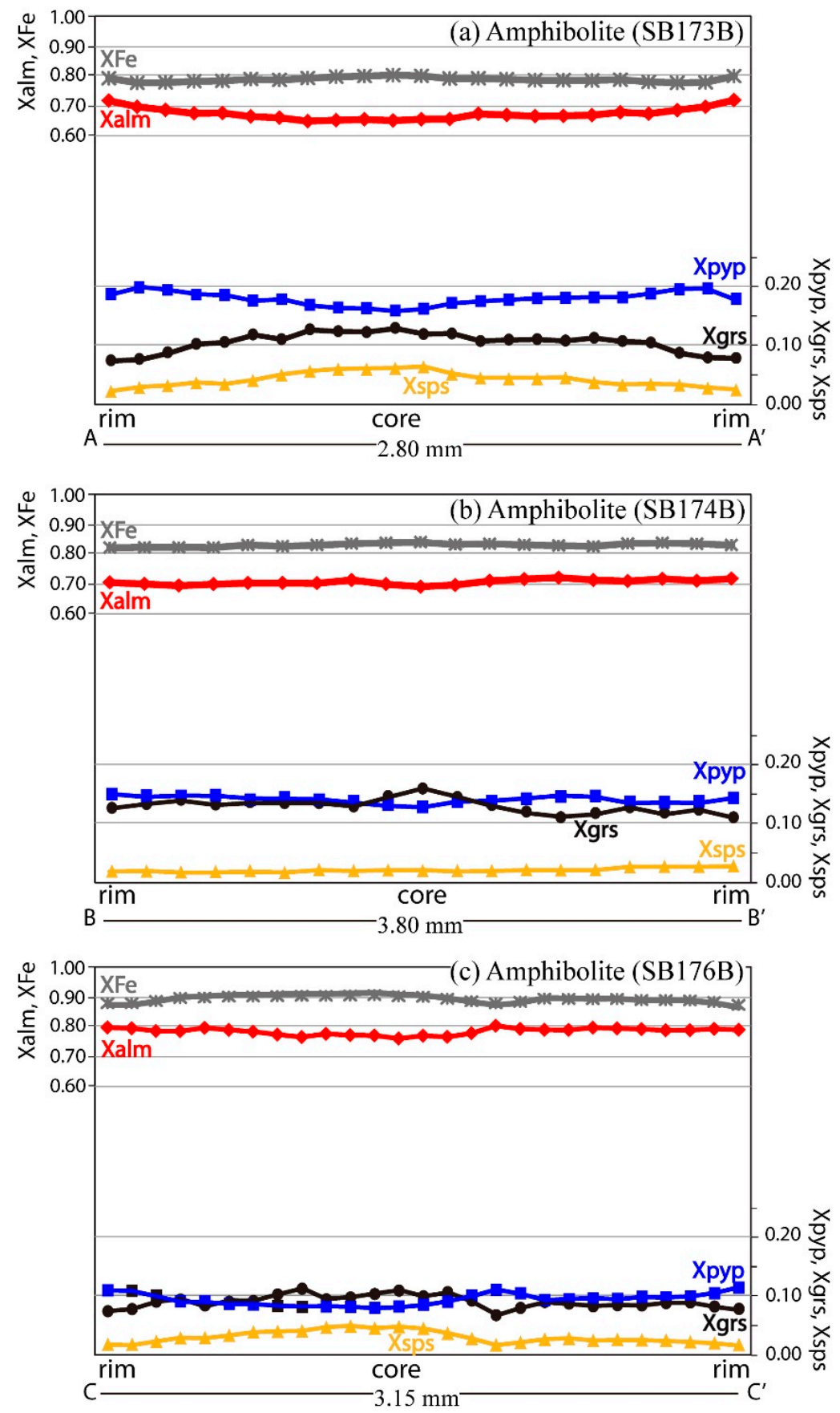

Figure 8. Representative compositional zoning profiles of garnet in amphibolites from the Dessent Unit. (a) Garnet porphyroblast of the amphibolite (SB173B), (b) a part of the elongated garnet band of the amphibolite (SB174B) and (c) garnet porphyroblast of the amphibolite (SB176B). Each profile and profile composition are presented in Figure 4 and Table S3, respectively.

\subsection{Amphibolite (SB174B) from the Dessent Unit}

Sample SB174B is a mylonitic amphibolite and is geochemically equivalent to basaltic andesite. The amphibolite (SB174B) is characterized by alternating hornblende- and garnet-rich layers in which hornblendes are strongly aligned or form fine-grained aggregates and garnets form elongated bands. Recrystallized plagioclase and quartz ribbons are mainly observed (Figures $3 \mathrm{c}$ and $4 \mathrm{~b}$ ). Pseudosection modeling of the amphibolite (SB174B) in a pressure range of 1-11 kbar reveals a clinoamphibole stability temperature lower than $\sim 730^{\circ} \mathrm{C}$ and a solidus (melt-in) temperature of $\sim 700{ }^{\circ} \mathrm{C}$. The thermal 
peak assemblage of the amphibolite (SB173B) is hornblende + plagioclase + garnet + biotite + quartz + ilmenite \pm melt, which is stable at a P-T range of $600-680{ }^{\circ} \mathrm{C}$ and $5.3-11.0 \mathrm{kbar}$ (Figure 9a). The compositional isopleths of garnet were applied to the pseudosection. The garnet layers are mostly almandine-rich $\left(X_{\mathrm{alm}}=0.66-0.73\right)$ and spessartine-poor $\left(X_{\mathrm{sps}}=0.01-0.04\right)$. The elongated garnet shows $X_{\text {pyp }}$ values of $\sim 0.13$ and $X_{\text {grs }}$ values of $0.16-0.19$ in the core, with a rim-ward compositional increase in $X_{\text {pyp }}(0.14-0.15)$ and a rim-ward decrease in $X_{\text {grs }}(0.11-0.14)$ (Figure $\left.8 b\right)$. The garnet core composition records a slightly higher $\mathrm{P}$ condition $\left(\sim 600^{\circ} \mathrm{C}\right.$ and $\left.\sim 10.2 \mathrm{kbar}\right)$ compared to the $\mathrm{P}-\mathrm{T}$ range inferred from the peak mineral assemblage. The $\mathrm{P}-\mathrm{T}$ conditions of garnet rims converge to the $\mathrm{P}-\mathrm{T}$ range inferred from the main mineral assemblage, yielding a peak temperature $\mathrm{P}-\mathrm{T}$ condition of $650-670{ }^{\circ} \mathrm{C}$ and 7-8 kbar. The GH and GHPQ geothermobarometry P-T conditions of the garnet rim, which is relatively spessartine-rich, are most likely those of retrograde processes (Figure 9b).

MnNCKFMASHT (+ qtz), Garnet amphibolite (Dessent Unit, SB174B)

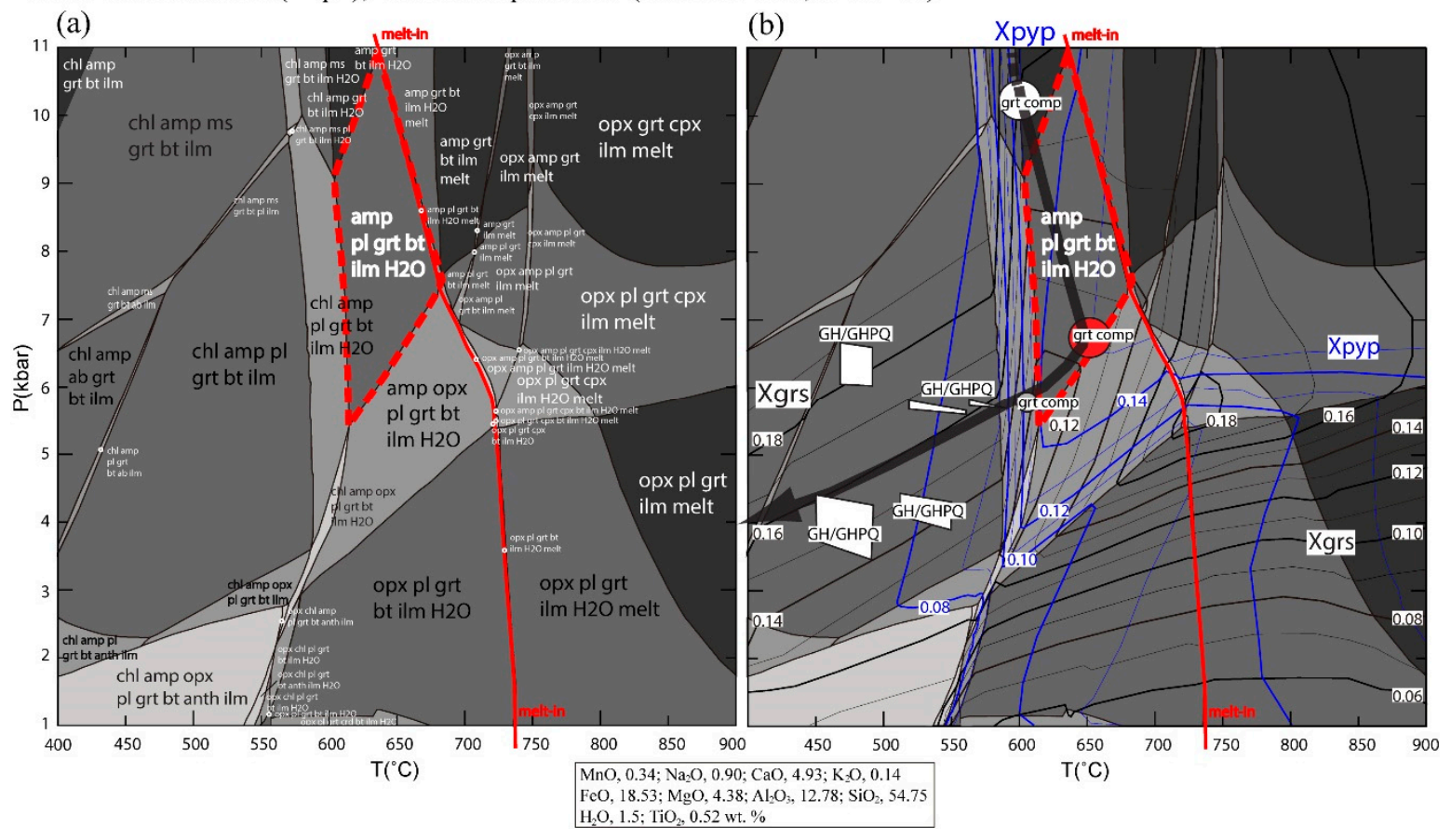

Figure 9. (a) P-T pseudosection for the amphibolite (SB174B) in the MnNCKFMASHT system. (b) P-T pseudosection with compositional isopleths of garnet for pyrope and grossular. The $\mathrm{P}-\mathrm{T}$ path is identified by the garnet isopleths and GH/GHPQ geothermobarometry. Mineral abbreviations are the same as those in Figure 7.

\subsection{Amphibolite (SB176B) from the Dessent Unit}

Sample SB176B is a mylonitic amphibolite and is geochemically equivalent to dacite. In this sample, the stretching lineation of hornblendes is well developed, and the recrystallized quartz forms an elongated band or polygonal granoblastic fabric (Figure $4 \mathrm{~d}, \mathrm{e}$ ). The peak metamorphic assemblage of the amphibolite is considered to be hornblende + plagioclase + garnet + biotite + quartz + ilmenite + magnetite. Pseudosection modeling of the amphibolite in a pressure range of 1-11 kbar reveals a clinoamphibole stability temperature lower than $\sim 750{ }^{\circ} \mathrm{C}$ and a solidus (melt-in) temperature of $\sim 700^{\circ} \mathrm{C}$. The stable metamorphic condition estimated by the thermal peak mineral assemblage corresponds to a $\mathrm{P}-\mathrm{T}$ range of $570-670{ }^{\circ} \mathrm{C}$ and $5.5-11.0 \mathrm{kbar}$ (Figure 10a). Garnet porphyroblasts are mostly almandine-rich $\left(X_{\mathrm{alm}}=0.74-0.83\right)$ and spessartine-poor $\left(\mathrm{X}_{\mathrm{sps}}=0.01-0.05\right)$. The core of the garnet porphyroblast shows $X_{\text {pyp }}$ values of $0.08-0.10$ and $X_{\text {grs }}$ values of $0.09-0.12 . X_{\text {pyp }}(\sim 0.11)$ increases marginally rim-ward, while $X_{\text {grs }}(0.05-0.07)$ decreases (Figure 8a). The P-T conditions of the garnet porphyroblast cores estimated by a compositional isopleth method are $570-600{ }^{\circ} \mathrm{C}$ 
and 5.3-6.8 kbar, which are close to the lower limit of the $\mathrm{P}-\mathrm{T}$ range inferred from the phase assemblage. The geothermobarometry (GH and GHPQ)-calculated metamorphic conditions of the garnet rim, which is relatively spessartine-rich, suggests several retrograde $\mathrm{P}-\mathrm{T}$ conditions converging to the $\mathrm{P}-\mathrm{T}$ condition of $\sim 420^{\circ} \mathrm{C}$ and $4.5 \mathrm{kbar}$ (Figure $10 \mathrm{~b}$ ).

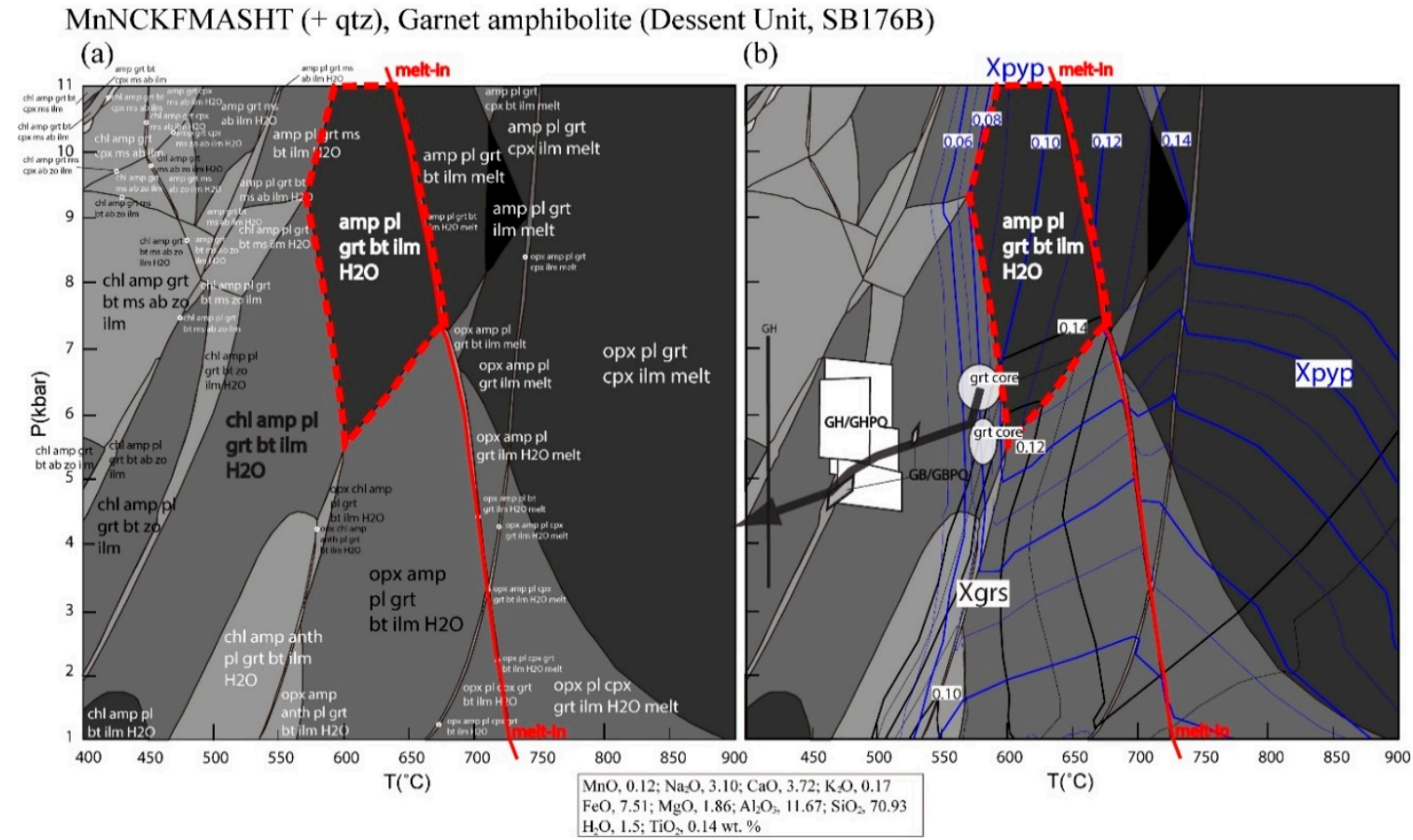

Figure 10. (a) P-T pseudosection for the amphibolite (SB176B) in the MnNCKFMASHT system. (b) P-T pseudosection with compositional isopleths of garnet porphyroblast for pyrope and grossular. The P-T path is identified by the garnet isopleths and GH/GHPQ and GB/GBPQ geothermobarometries. Mineral abbreviations are the same as those in Figure 7.

Summing up the metamorphic P-T conditions of the three amphibolite samples, the Dessent Unit underwent metamorphism during the Ross Orogeny. This process consists of the higher pressure $\mathrm{M}_{1}\left(\sim 600{ }^{\circ} \mathrm{C}\right.$ and $\left.10.0-10.5 \mathrm{kbar}\right)$ and the thermal peak $\mathrm{M}_{2}\left(\sim 700{ }^{\circ} \mathrm{C}\right.$ and $\left.7.0-7.5 \mathrm{kbar}\right)$, followed by the retrograde $\mathrm{M}_{3}\left(\sim 450^{\circ} \mathrm{C}\right.$ and $\left.4.0-4.5 \mathrm{kbar}\right)$ (Figure 11$)$. 


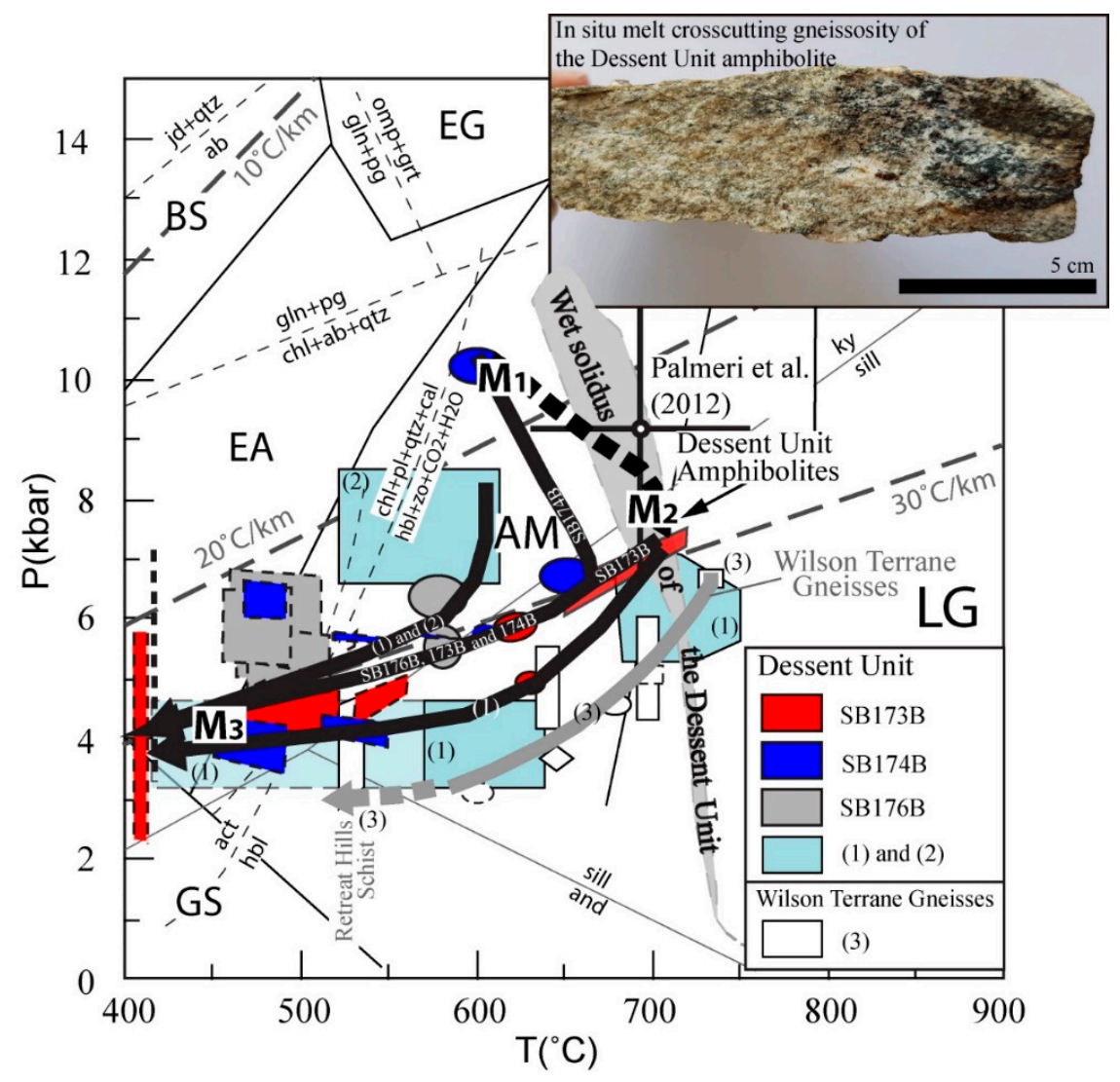

Figure 11. Summarized P-T paths of the Mountaineer Range, including the Dessent Unit and the Wilson Terrane gneisses. An amphibolite hand specimen hosting in situ melt collected from the Dessent Unit could represent its $\mathrm{M}_{2}$ stage metamorphism. Prograde $\mathrm{P}-\mathrm{T}$ conditions are presented as solid line polygons and retrograde $\mathrm{P}-\mathrm{T}$ conditions as dot line polygons. Literature $\mathrm{P}-\mathrm{T}$ conditions include (1) Scambelluri et al. [62]; (2) Capponi et al. [97]; (3) Castelli et al. [98]; (4) Palmeri et al. [59]. The P-T paths from the literature data are inferred by this study. Reference reaction curves: Plyusnina [99], Ernst [100], Spear [101] and Bucher and Frey [102]. Petrogenetic grid: Oh and Liu [103]. Abbreviations: BS, blueschist facies; EG, eclogite facies; EA, epidote amphibolite facies; GS, greenschist facies; LG, low-pressure granulite facies; jd, jadeite; gln, glaucophane; omp, omphacite; pg, paragonite; cal, calcite; act, actinolite; ky, kyanite; sill, sillimanite; and, andalusite. Other mineral abbreviations are the same as those in Figure 7.

\section{Discussion}

The Ross-Delamerian Orogen had a profound impact on the formation of the Paleozoic eastern Gondwana (i.e., East Antarctica-TAM, eastern Australia, Tasmania and southern Zealandia). In addition, Antarctica and Australia shared a variety of geological events in the Precambrian. These are represented by the Archean to Paleoproterozoic Mawson Craton (an amalgam comprising the Gawler, Terre Adélie, Nimrod and Shackelton components), its right-hand side (RHS in Figure 1d co-ordinates: VL direction) Nimrod-Kimban Belt (c. 1.7 Ga) and left-hand side (LHS in Figure 1d co-ordinates: Prince Charles Mts. direction) Kararan (1.64-1.55 Ga), Albany-Fraser (1.34-1.14 Ga) and Pinjarra-Grenville (1080-990 Ma) orogenic belts. The middle Paleozoic Lachlan Orogeny also influenced the formation of West Antarctica, eastern Australia, Tasmania and southern Zealandia (Figure 1d). Geological similarities between Antarctica and adjacent regions have led to various studies related to the assembly and breakup of Gondwana [3,14,42,53,104-106].

The amount of rock exposure in Antarctica is extremely limited. Thus, the detrital zircon ages, identified in (meta)sedimentary rocks have helped greatly with the interpretation of the provenance of detritus as well as with the possible lithology under the currently obscured glaciers and the development 
of the paleocurrent pattern and paleogeographic linkage. In the following sections, we infer the origin of the sediments of Mt. Murchison (para-)gneiss, and then, we discuss the protolith formation process of the gneiss, the metamorphic evolution in the Mountaineer Range and tectonic model for the Ross Orogeny in NVL.

\subsection{Possible Provenance of Detrital Zircons in the Mt. Murchison Gneisses (WT)}

The age distribution of detrital (or xenocrystic) zircon found in the Murchison gneisses and granite (WT) is characterized by predominant ages of c. $565 \mathrm{Ma}$ and 900-1200 Ma (Grenville-age), with minor age abundances of 600-650 Ma, 700-800 Ma, c. $1400 \mathrm{Ma}$, c. $1670 \mathrm{Ma}$, c. $1800 \mathrm{Ma}$, c. $2250 \mathrm{Ma}$ and c. $2450 \mathrm{Ma}$ (Figure 12). In order to estimate the provenance of the detrital zircons found in the Mt. Murchison rocks, we would like to summarize the major geological events throughout the entire TAM region, including the study area (N)VL, and in the East Antarctic interior. The location of the mentioned provenance and its proximity to the NVL can be seen in Figures 1d and 13a. East Antarctic Archean to Paleoproterozoic rocks adjacent to the TAM regions were identified in the Mawson Craton. Among these, the rocks of the Terre Adélie Land and Nimrod Complex are thought to be involved in the protolith development of the NVL (meta)sedimentary rocks. The Paleoproterozoic detrital zircons (2.45-1.80 Ga) identified in the Mt. Murchison rocks are thought to originate from these regions. The Paleoproterozoic Nimrod-Kimban Belt (c. 1.7 Ga) and Kararan Belt (1.64-1.55 Ga) could be the possible provenance of the Mt. Murchison c. 1.67 Ga zircon. The Trans-Laurentian Igneous Suite (T-LIS, 1.49-1.37 Ga) developed into LHS of the Mawson Craton, and this region is likely the origin of the Mt. Murchison c. 1.4 Ga zircon. The Mt. Murchison rocks are represented by the major population of the Grenville-age detrital zircons (1.2-0.9 Ga). The East Antarctic part of the Pinjarra-Grenville belt (1.08-0.99 Ga), which runs through East Antarctica to western Australia, could be the provenance of these zircons, and the Albany-Fraser Belt (1.34-1.14 Ga), which connects East Antarctica to Australia, also could be the origin of Mt. Murchison's Grenvillian detrital zircon.

The Neoproterozoic passive margin formed in RHS of the Mawson Craton. These regions can be interpreted as rift basins associated with the breakup of Rodinia, and their main rifting period is predicted to be 750-650 Ma [5,26,107]. Although the detected continental rift-related U-Pb zircon crystallization age in the outcrop is limited to $670 \mathrm{Ma}$ (central TAM [108]) and 650 Ma (southern VL [109]), it is expected that more 750-650 Ma-age rocks obscured by glaciers could be present in the estimated rift basin. These ages can cover the 800-650 Ma detrital zircon age within Mt. Murchison. The outcrop record for the early Ross Orogeny in the TAM region, including the study area, is a zircon $\mathrm{U}-\mathrm{Pb}$ age of $550 \mathrm{Ma}$. In addition, the zircon $\mathrm{U}-\mathrm{Pb}$ ages obtained from glacial clasts or detrital materials makes it possible to estimate the Ross Orogeny activity during the period 590-550 Ma, and the c. $615 \mathrm{Ma}$ metamorphism (garnet Lu-Hf date) retained by the central TAM basement rock leads to inference of the initiation period of 615-590 Ma for the Ross Orogeny [26,107,110]. The mentioned early Ross orogenic ages are most frequent in Mt. Murchison's detrital zircons and also are equivalent to the youngest detrital zircon age of the gneiss sample (SBM173) (Figure 6a,b and Figure 12). Thus, the protolith of the Mt. Murchison paragneiss is expected to be a sedimentary rock formed during the early Ross Orogenic process. Syn-orogenic forearc deposition associated with the Ross Orogeny has been predicted throughout VL and in the central TAM region [3,26,28,41,111]. The youngest detrital zircon age of the Mt. Murchison gneiss (SBM173B) is $562.4 \pm 6.0 \mathrm{Ma}$, and the metamorphism is interpreted to have lasted for a period of 530-480 Ma (see Section 5 and Figure 6a,b). This indicates that the protolith of the Mt. Murchison (para)gneiss was formed between 560-530 Ma. Furthermore, the protolith could be formed in the forearc during this period, and it can be considered that old detritus originating from the interior of East Antarctica was introduced into the forearc (Figure 13). 


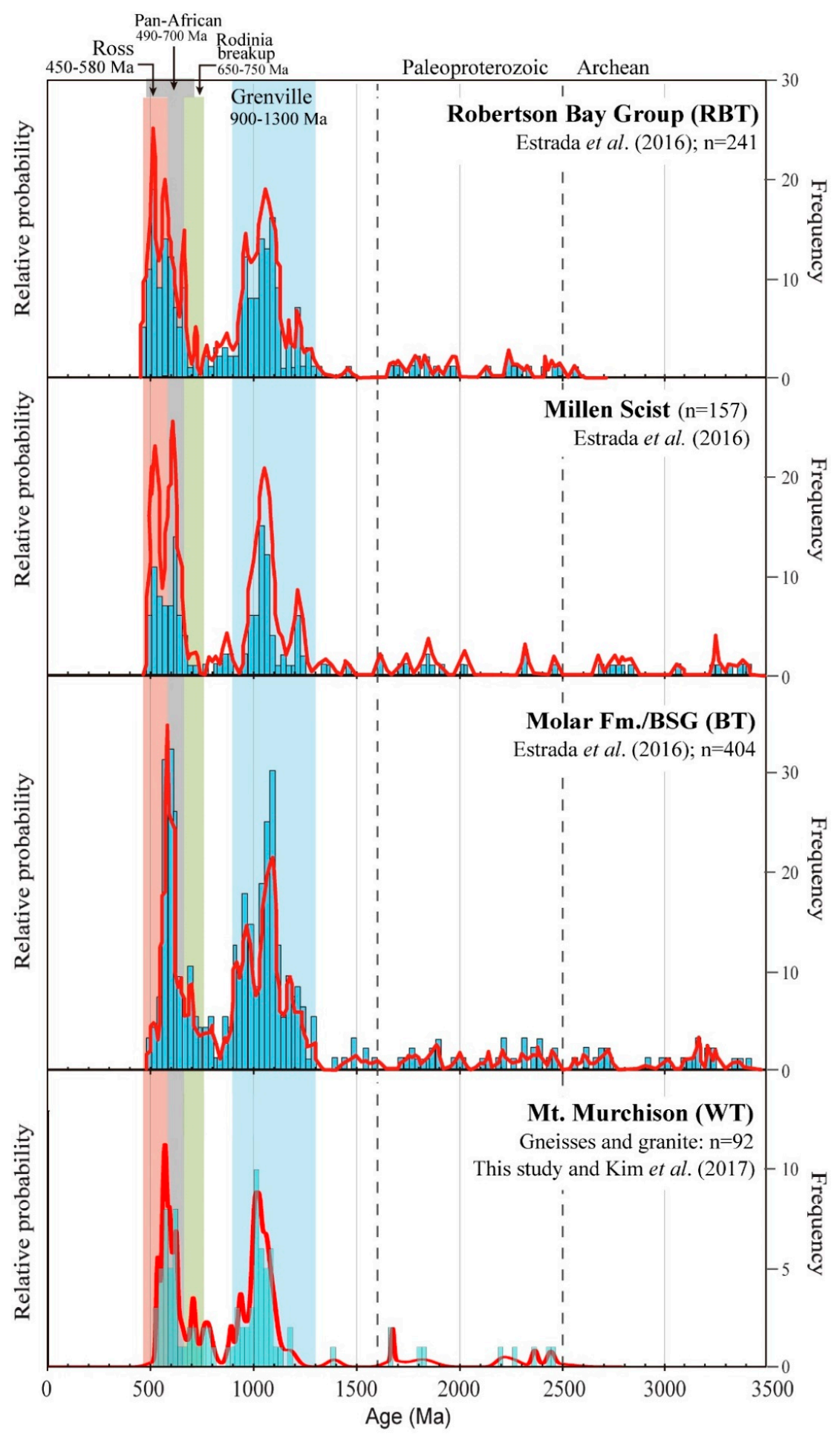

Figure 12. A comparison of detrital zircon (xenocrystic zircon for granite) ages from the major Ross-orogenic lithologies of NVL. Relative probability distribution-frequency histograms for concordant (less than 10\% discordance) $\mathrm{U}-\mathrm{Pb}$ ages. All three terranes (WT, BT and RBT) exhibit a similar detrital age distribution featuring the Grenvillian and Ross/Pan-African ages. The BT and RBT are especially characterized a prominent Ross-orogenic detritus. Literature data include Estrada et al. [39] and Kim et al. [48]. 


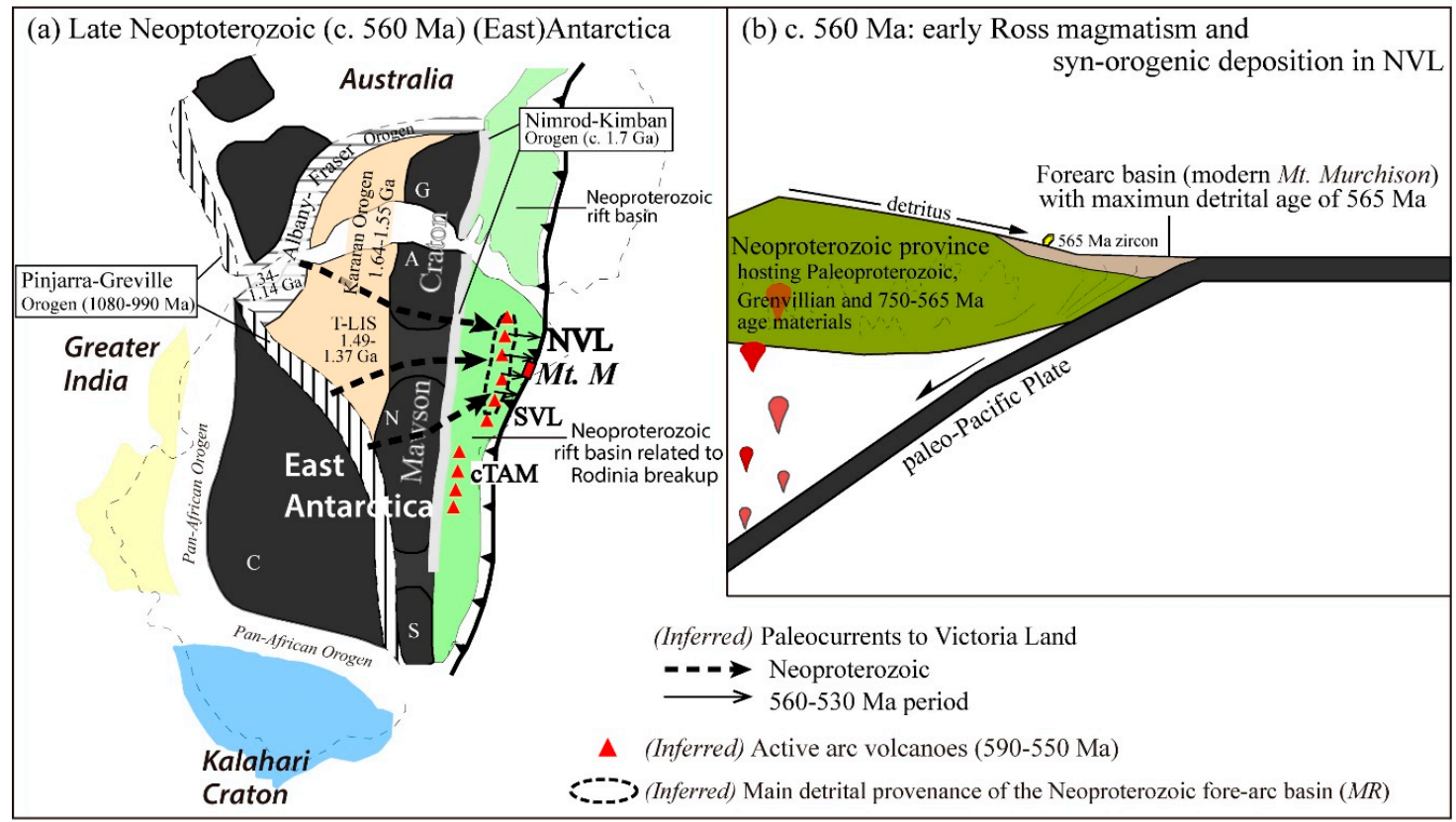

Figure 13. (a) Paleogeographic map showing late Neoproterozoic (Ediacaran, c. 560) Antarctica and its tectonic environment and relationship with surrounding eastern Gondwana blocks (modified after $[5,26,39,107])$. Mt. M: late Neoproterozoic location of the proto-sedimentary basin of the modern Mt. Murchison. (b) Ediacaran (c. $560 \mathrm{Ma}$ ) NVL during the early Ross-orogenic (inferred) period and a possible proto-sedimentary basin (forearc basin) of the Mt. Murchison paragneiss. Continental arc magmatism and related syn-orogenic deposition are expected to have occurred.

The Pan-African Orogen is a Gondwana-building tectonic process that completes the assembly of eastern and western Gondwana. This orogeny is detected around the Crohn Craton in Antarctica and has an orogenic age range from 580 to $490 \mathrm{Ma}$ (up to $700 \mathrm{Ma}$ in the East African Orogen) $[2,4,5,12,112]$. In other words, the Pan-African Orogeny occurred at nearly the same time as the Ross(-Delamerian) Orogen, and it corresponds to the Ediacaran detrital zircon age in the Mt. Murchison area. However, considering the distance between the Pan-African belts and the study area and the relationship between the study area and the Ross Orogeny, it is expected that the Pan-African Orogen-related detritus did not have much of an impact on the formation of the proto-Mt. Murchison basin (Figures 1d and 13). Yet, the relationship between the Pan-African Orogen and the formation of VL should be discussed in more depth in the future.

Possible source materials mentioned above could be interpreted as being directly deposited into the protolith sedimentary basin of the modern Mt. Murchison through the Neoproterozoic to early Paleozoic currents. However, if the existence of the Ediacaran (590-550 Ma) Ross igneous province is acknowledged, the magmatic arc mountains (e.g., the modern equivalent could be the Cascade Range or Andes Mts.) of this igneous process can be expected to act as a barrier to paleocurrents. That is, it can be interpreted that the sedimentary basins of the Mt. Murchison protolith do not receive Proterozoic detritus directly from the East Antarctic interior, but rather receive them from late Neoproterozoic (Ediacaran) arc mountains hosting reworked (Paleo- to Neo-)Proterozoic sediments as well as early Ross orogenic material (Figure 13).

To summarize, the above discussion indicates that protoliths of the Mt. Murchison gneisses are sedimentary rocks formed at a certain period between 560 and $530 \mathrm{Ma}$ and that the detrital source of the protoliths could be a Neoproterozoic crust hosting Paleoproterozoic, Grenvillian and 750-565 Ma age materials (possibly including the early Ross orogenic materials). This Neoproterozoic crust could be a marginal supracrustal province (i.e., platform) reworking of initial sources from the East Antarctic interiors (i.e., shield). Thus, possibly a Proterozoic shield (hosting an Archean lithology) 
and platform-late Neoproterozoic to Paleozoic magmatic arc association during the Paleozoic era can be specified as a geological architecture in East Antarctica and the TAM region, including NVL.

\subsection{Early Paleozoic Metamorphic Phase (Ross Orogeny) in the Mountaineer Range}

The metamorphic evolution and P-T conditions of the Ross Orogeny in the Mountaineer Range have been presented by several studies $[59,62,97,98]$. The metamorphic $\mathrm{P}-\mathrm{T}$ conditions were obtained in the Dessent Unit and the WT margin gneisses. This section discusses the metamorphic P-T condition of the Dessent Unit obtained in this study and the published data. As mentioned in Section 6, the metamorphic conditions established in the Dessent Unit are divided into three stages: higher $P$ $\left(\mathrm{M}_{1}\right)$, peak $\mathrm{T}\left(\mathrm{M}_{2}\right)$ and retrograde $\left(\mathrm{M}_{3}\right)$. Palmeri et al. [59] presented the peak P-T condition comparable to the metamorphic condition of the middle path between $\mathrm{M}_{1}$ and $\mathrm{M}_{2}$. In addition, the P-T conditions presented by Capponi et al. [97] are similar to those obtained for the amphibolite sample (SB176B). Moreover, the conditions of Scambelluri et al. [62] show a metamorphic P-T path similar to that of $\mathrm{M}_{2}-\mathrm{M}_{3}$ in this study, although the metamorphic pressure of Scambelluri et al. [62] is relatively lower. Based on this, we can infer that the Dessent Unit has undergone an intermediate P/T-type metamorphism characterized by $\mathrm{M}_{1}\left(\sim 600{ }^{\circ} \mathrm{C}\right.$ and 10.0-10.5 kbar), $\mathrm{M}_{2}\left(\sim 700{ }^{\circ} \mathrm{C}\right.$ and 7.0-7.5 kbar) and $\mathrm{M}_{3}\left(\sim 450^{\circ} \mathrm{C}\right.$ and $\left.4.0-4.5 \mathrm{kbar}\right)$ (Figure 11). This clockwise P-T path of the Ross Orogeny tends to appear differently at each location within the unit. This can be attributed to local differences in thermal effects associated with mafic to intermediate intrusions in the Mountaineer Range.

Based on the results of Sections 5 and 6, the Ross Orogeny is highlighted by dynamothermal metamorphism and the intrusion of igneous rocks from $520 \mathrm{Ma}$ to $480 \mathrm{Ma}$ (Figure 6). This study determined that within this period, c. $515 \mathrm{Ma}$ and c. $500 \mathrm{Ma}$ possibly represent the $\mathrm{M}_{1}$ and $\mathrm{M}_{2}$ stages of the Dessent Unit, respectively. That is, the high-T metamorphism (a boundary P-T condition between the amphibolite and granulite facies) of the $\mathrm{M}_{2}$ stage is only recognized in some areas of the Dessent Unit, and this pattern is likely to be attributed to the local distribution of identified or hidden c. $500 \mathrm{Ma}$ intrusives. In this study, several samples with partial melting can be identified (Figure 11). In addition, the clinopyroxene-bearing granulite recovered at Frank Point [62] indicates that some parts of the Dessent Unit underwent granulite facies metamorphism, which is related to the major intrusion period of igneous rocks and is the result of the Dessent Unit $\mathrm{M}_{2}$ metamorphic phase.

Most of the rocks in the Dessent Unit were mylonitized. Chlorite and epidote developed along the mylonitic foliation with S-C fabric and ECC (Figure 4a). This indicates that the unit was predominantly mylonitized under a greenschist facies metamorphic condition ((post-) $\left.\mathrm{M}_{3}\right)$. However, garnet deformation from brittle to crystal-plastic transition, the development of garnet bands, alternating garnet and hornblende layers and the presence of granoblastic polygonal quartz and quartz ribbon in several samples indicate that the mylonitization of these rocks occurred under an amphibolite facies metamorphic condition (pre- $\mathrm{M}_{3}$ : Figures $3 \mathrm{c}$ and $4 \mathrm{~b}, \mathrm{e}$ ). Furthermore, since most of the prograde and retrograde metamorphic $\mathrm{P}-\mathrm{T}$ conditions of the Dessent Unit obtained in this study correspond to the amphibolite facies condition (Figure 11), it can be interpreted that the mylonitization of the unit also started to occur under the amphibolite facies $\mathrm{P}-\mathrm{T}$ condition (pre- $\mathrm{M}_{3}$ stage). That is, the greenschist facies mylonitization ((post-) $\left.\mathrm{M}_{3}\right)$, which is predominant in the outcrops, may correspond to a secondary metamorphic event that overprinted the amphibolite facies mylonitization related to the peak metamorphism of the Dessent Unit $\left(\mathrm{M}_{1-2}\right)$. Thus, the first mylonitization may have occurred during the peak metamorphic process (amphibolite facies) in the geologically deeper location of the Dessent Unit $\left(\mathrm{M}_{1-2}\right)$. Then, the unit may have undergone extension-related shearing (e.g., ECC) during the retrograde process (greenschist facies: (post-) $\mathrm{M}_{3}$ ).

The metamorphic P-T condition of gneisses from the WT margin is similar to that of the Dessent Unit. However, the WT margin gneisses have a relatively lower pressure condition than most of the Descent Unit amphibolites (Figure 11) [62,97]. Given the Wilson Terrane margin and the Dessent Unit's proximity, these two zones appear to have experienced the same metamorphic process during the Dessent Unit $\mathrm{M}_{2}-\mathrm{M}_{3}$ phase. It is assumed that the migmatization of the Wilson gneisses (c. $500 \mathrm{Ma}$ ) 
is associated with the $\mathrm{M}_{2}$ phase of the Dessent Unit, which was activated by igneous activity in the regions adjacent to the Dessent Unit (i.e., tectonic boundary) at approximately $500 \mathrm{Ma}$.

The Tonalite Belt developed between the WT and the Dessent Unit. The igneous ages of the tonalite are $499.3 \pm 2.1 \mathrm{Ma}$ (SB1713A: Figure $6 \mathrm{c}$, this study) and $489 \pm 4 \mathrm{Ma}$ [65], with a slight age difference locally. A weak mylonitic fabric that appears in the tonalite (SB1713A) indicates that the Tonalite Belt was ductilely deformed even after 500 Ma.

The Husky Ridge intrusion was reported in contact with the WT gneisses and the Tonalite Belt (Figure 2) [65]. The Husky Ridge intrusion consists of mafic intrusive rocks, typically with amphibole as the characteristic mineral. These rocks have an ambiguous contact relationship with the WT gneisses and the Tonalite Belt. The igneous age of the Husky Ridge quartz diorite (or hornblende gabbro) was reported as $516 \pm 3 \mathrm{Ma}$ [65]. This intrusion is found in an undeformed or weakly deformed nature. Considering the peak metamorphism at c. $500 \mathrm{Ma}$ identified in this area and the location of the intrusion, which corresponds to the tectonic boundary, the undeformed nature of the Husky Ridge Intrusion may contradict the c. $515 \mathrm{Ma}$ igneous age of the quartz diorite. Similar samples of hornblende gabbro (M1722 and M1719) and tonalite (SB1713A) comprising hornblende and plagioclase minerals with igneous ages of c. $500 \mathrm{Ma}$ are found in this study. Since the reported quartz diorite from the Husky Ridge also contains a number of c. 500 Ma single zircon ages, the reported igneous age of $516 \pm 3$ Ma has a possibility to be revised. If the Husky Ridge intrusion is a local intact rock of hornblende gneiss of the WT, which survived the Ross-dynamothermal metamorphism, the c. $515 \mathrm{Ma}$ age could also be interpreted as the protolith age of the hornblende gneiss.

The BSG zone comprises greenschist/phyllite and (meta)igneous rocks consisting of subvolcanic hornblende gabbro and granite porphyry/granodiorite. They form tightly to isoclinal folds and are partially mylonitized. Their fold axial planes are generally sub-parallel to the mylonitic foliation of the Dessent Unit. A metasedimentary rock from the BSG zone contained the Ross Orogen-related detrital zircon $(511 \pm 15 \mathrm{Ma}, 526 \pm 13 \mathrm{Ma}$ and $540 \pm 8 \mathrm{Ma})$ indicative of the basin formation for this zone during the Ross Orogeny [39]. This zone appears to have undergone greenschist facies metamorphism.

Deformational structures of the Mountaineer Range are summarized as follows. The Murchison gneisses (WT) and the BSG (BT) were folded with a similar aspect by a regional compression driving into the direction of NE-SW, and the Dessent Unit between them was mylonitized by compression-related shearing. This can be explained by an orogenic process in which a regional compression juxtaposed the WT and BT, strongly shearing their tectonic boundaries (e.g., [33,34,43,44,59]). The recognition of intermediate $\mathrm{P} / \mathrm{T}$-type metamorphism and the absence of eclogite or related high-pressure mineral assemblages in the Dessent Unit indicates that the exposed unit was not significantly subducted into the deep depth (i.e., eclogite facies condition) during the union of the WT and BT. This differs from the Lanterman Range, for which high P/T-type metamorphism with eclogite facies $\mathrm{P}-\mathrm{T}$ conditions are reported $[58,60,61,113,114]$. However, a clockwise $\mathrm{P}-\mathrm{T}$ path in which a high-pressure stage at c. 515 Ma proceeded by high-temperature metamorphism at c. 500 Ma reported in the Lanterman Range [61] indicates that both the Mountaineer Range and the Lanterman Range ultimately experienced a metamorphic evolutionary path of similar timing (duration) and stages.

\subsection{Possible Tectonic Model for the Ross Orogeny in the Mountaineer Range}

Several tectonic models have been proposed for the Ross Orogeny that complete the formation of NVL. These are based on the model of Kleinschmidt and Tessensohn [41]. The Kleinschmidt and Tessensohn model is based on the subduction of ocean plates into the continental margin WT and the related BT and RBT accretion. This model assumes two parallel, westward-dipping subduction zones, in which an island arc (Glasgow Volcanics) formed by rear subduction and the BT was completed during the WT-arc collision process. The tectonic environment then changes to single slab subduction and the RBT began to grow (similar to Figure 14). After the Kleinschmidt and Tessensohn model, a continent (WT)-(micro)continent collision model was proposed [37,42]. The new model suggests that the Wilson continental arc developed in the convergence process of the two continents, 
then arc (Glasgow Volcanics) and back-arc (or forearc, BT) developed by slab roll-back, and finally, the continental-continent collision accelerated the RBT formation over the following continent that is now totally covered by the thick RBT (turbiditic) sediments. Rocchi et al. [31] predicted that subduction of the paleo-Pacific Plate into the Gondwana margin caused the development of the Wilson continental arc (WT), and during this process, the continental affinity-forearc was boudinaged into two blocks (Bowers arc and Admiralty continental ribbon). After that, the two blocks were reassembled by contraction, and the outboard island arc (Tiger arc) finally accreted to complete NVL.

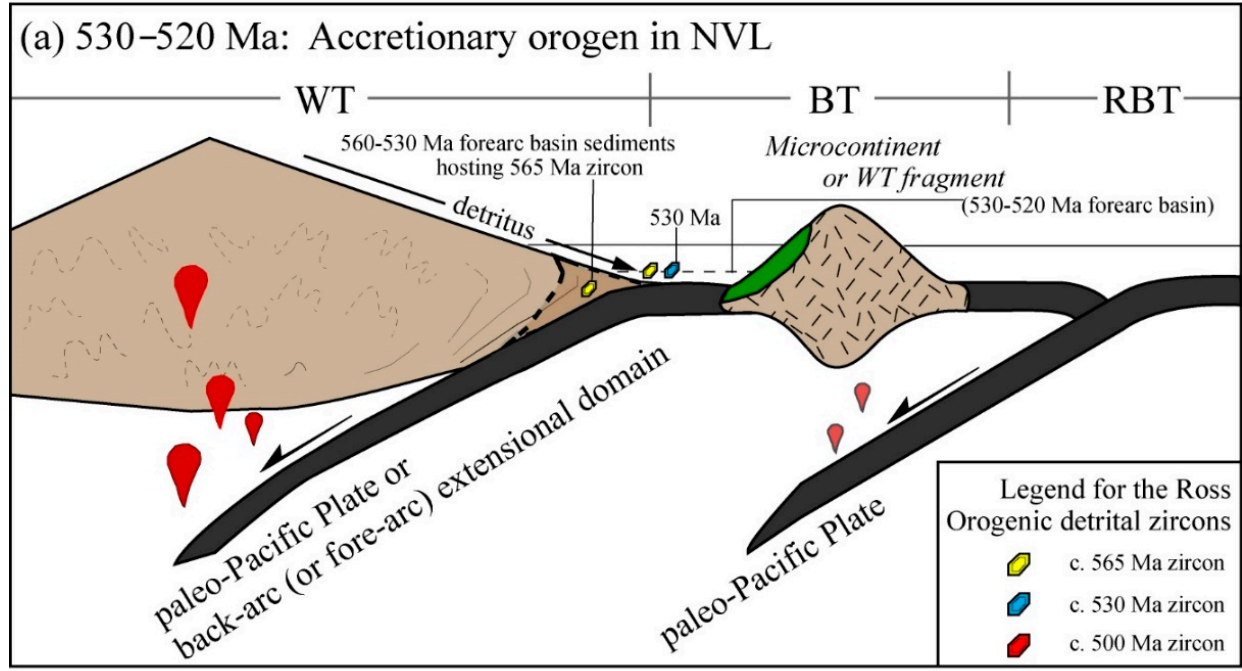

(b) 500 - 490 Ma: Continent (WT)-Arc (BT) collision in the Mountaineer Range

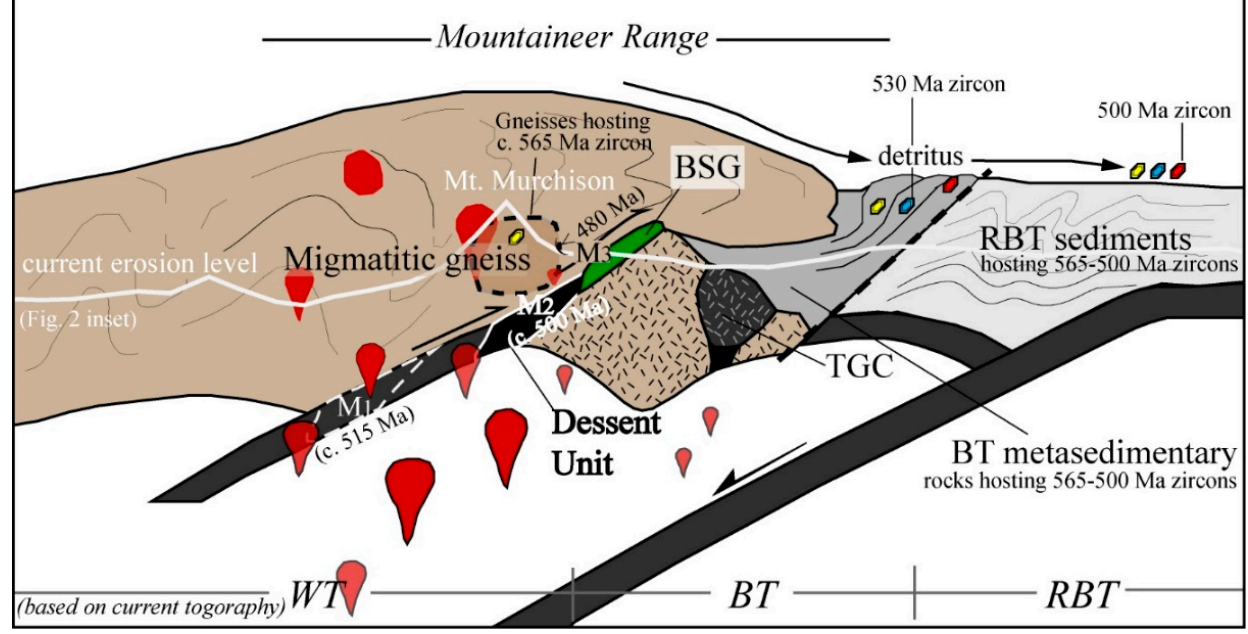

Figure 14. The tectonic model for the Ross Orogeny in the Mountaineer Range. (a) Accretionary orogeny (530-520 Ma) and syn-orogenic deposition of arc-derived detritus: there exist two parallel subduction zones and early Cambrian magmatism comparable with plutons in the WT interior (e.g., [15,31,49-51]). (b) Continent (WT)-arc (BT) collision, magmatism and migmatization (peak at c. $500 \mathrm{Ma}$ ): the Dessent Unit could be a mixture of an arc-extension related igneous body and sedimentary strata, which would have subducted underneath the WT before the 500 Ma period. The predominant igneous event (c. 500 $\mathrm{Ma}$ ) affecting the dynamothermal structure (e.g., migmatization) within the Mountaineer Range might have been the result of subduction of the paleo-Pacific Plate into the WT-BT union. Metamorphic stages of the Dessent Unit with the trace of the $\mathrm{M}_{1}$ (c. $\left.515 \mathrm{Ma}\right)-\mathrm{M}_{2}$ (c. $\left.500 \mathrm{Ma}\right)-\mathrm{M}_{3}(<480 \mathrm{Ma})$ transition. Deposition of the detrital zircon related to the WT-BT-RBT association is inferred. Current erosion level shows the topography of the Mt. Murchison area and the adjacent area (inset in Figure 2). The model and artwork are modified after Boger and Miller [3] and Kleinschmidt and Tessensohn [41]. 
It is possible to visualize the aspect of the Ross Orogeny in the Mountaineer Range by combining the contents of Sections 7.1 and 7.2 and previous studies. The WT forms a continental margin at East Antarctica during the late Neoproterozoic to early Paleozoic. The dominant igneous activity of the Ross Orogen in the WT occurred from 530 to 480 Ma [15,31,49-51], and in the Mountaineer Range of the terrane margin, from 500 to $480 \mathrm{Ma}$ (this study) [48,65]. The age distribution of detrital zircon found in the Murchison gneisses is characterized by predominant ages of c. $565 \mathrm{Ma}$ and 900-1200 Ma (Grenville-age), with minor age abundances of Paleoproterozoic to Neoproterozoic ages. This is similar to the distribution pattern of detrital zircon found in the Molar formation and the BSG of the BT and in the Millen Schist and the RBT (Figure 12). In addition, igneous and metamorphic ages of the Ross Orogeny identified in the Mountaineer Range outcrop are recorded in the BT-RBT as the youngest detrital zircon ages. This indicates that the deposition of clasts primarily formed the BT-RBT sediments from the WT including the Wilson continental arc [38,39]. Furthermore, the strata of these two terranes are thought to be continuously deposited and intruded (or extruded) during the Ross Orogeny and simultaneously deformed to form the present WT-BT-RBT association. Consequently, NVL is characterized by the WT (East Antarctic margin), which is continuously subducted and accreted by oceanic-continental domains (BT and RBT) on which strata and arc magmatic rocks are formed and deformed. (Meta)igneous rocks identified in the BSG zone (BT) are thought to have been formed in arc environments and deformed (or metamorphosed) by process of continent-arc collision. The lithology of the hornblende gabbros and associated amphibole-featured igneous rocks (a members of the appinite suite) found in the vicinity of the Dessent Unit (BSG, TGC, Husky Ridge and Tonalite Belt) has been reported in an arc or post-arc tectonic settings (mainly in the continental regions) [115-120]. Neoarchean to Paleoproterozoic xenocrystic zircons are found in igneous cumulates of the TGC that is thought to have intruded the BT [72]. In addition, the presence of deformed granites in the BSG zone suggests the possibility that the BT is a submarine or subaerial arc on the continental crust.

With the limited data in this study, it is difficult to establish a tectonic model for the entire NVL. However, by combining the above-mentioned discussion and the advantages of preexisting models (especially in regard to Kleinschmidt and Tessensohn's model [41]), it becomes possible to draw a tectonic model for the formation of the Mountaineer Range as in the following two paragraphs.

This study and previous data from igneous rock clasts and detrital materials of VL indicate that the Ross Orogeny in NVL possibly began at least at $565 \mathrm{Ma}$. During the late Neoproterozoic era (Ediacaran), the WT was situated in the paleo-Pacific margin of East Antarctica (or eastern Gondwana), and the modern Mountaineer Range was located on the paleo-Pacific subduction zone (forearc basin) (Figure 13). A magmatic province related to the early Ross Orogeny (c. $565 \mathrm{Ma}$ ) was rapidly dismantled during the continuous Rose orogenic contractional process. Then, the clastic materials from the magmatic province were deposited in the WT margin (forearc basin) during 560-530 Ma (Figure 13b) and subsequently underwent the Ross-dynamothermal metamorphism (530-500 Ma) to be transformed into the Mt. Murchison gneiss (Figure 14). In other words, the protolith of the Mt. Murchison gneiss (WT) formed between the late Ediacaran (c. $560 \mathrm{Ma}$ )-early Cambrian (530 Ma) dominantly sourced from early Ross (Ediacaran) magmatic arc mountains (Figure 13).

A prominent igneous activity of the Ross Orogeny in NVL begins at distinct time in the 530-520 Ma period. This activity is predominantly identified within the WT interior [15,31,49-51]. This igneous activity corresponds to arc magmatism associated with the WT-BT union. Continental arc products formed during this period are eroded and then deposited in the forearc basin, where the materials become the parent of the BT silicic clasts (Figure 14a). The BT is a submarine or subaerial arc on the continental crust (allochthonous microcontinent or WT fragment), which consists of sedimentary deposits transported from the WT and igneous rocks associated with the subduction of the RBT oceanic plate (i.e., paleo-Pacific Plate). The Dessent Unit is developed between the WT and the BT as a high-grade metamorphic rock with a dominant basalt (or basaltic andesite) lithology. The Dessent Unit is thought to be an arc-related extensional domain including back-arc and fore-arc, or it could be a part of the paleo-Pacific Plate (e.g., [31,37,59], its origin is still unclear). This rock body subducts into 
the lower part of the WT, and the current rock body exposed at the surface shows a subduction depth of approximately $35 \mathrm{~km}$ (c. 10.0-10.5 kbar) ( $\mathrm{M}_{1}$, possibly $\left.515 \mathrm{Ma}\right)$. After subduction, the rock body rises to a shallow depth of approximately $23 \mathrm{~km}$ (c. $7 \mathrm{kbar}$ ) and experiences a thermal peak ( $\mathrm{M}_{2}$, possibly 500 $\mathrm{Ma}$ ) of the Ross Orogeny, which corresponds to the migmatization stage of the Mt. Murchison gneisses. Simultaneously, the Murchison gneisses undergo a compressive, dynamothermal metamorphism encompassing migmatization as a process of the WT-BT collision (at $500 \mathrm{Ma}$ ). The $\mathrm{M}_{2}$ phase of the Descent Unit leaves a trace of the concordant deformation on the Murchison-Dessent-BSG union (Figure 14b). The migmatization at $500 \mathrm{Ma}$ is related to the mafic to intermediate magmatism (within the Tonalite Belt and the TGC) around the Dessent Unit, which is thought to be arc igneous activity possibly associated with subduction of the RBT oceanic plate (paleo-Pacific Plate) into the BT. This magmatism extends to c. $480 \mathrm{Ma}$, causing the intrusion of leucocratic dykes (e.g., [48]) and the second stage of migmatization in Mt. Murchison. During the Ross Orogeny of the Mountaineer Range (530-480 Ma), the BT and RBT continue to grow and receive sediments from the WT. After the $500 \mathrm{Ma}$ period, the Dessent Unit undergoes retrograde metamorphism $\left(\mathrm{M}_{3}\right)$ and thrusts into the shallow, where a juxtaposition with the BSG occurs (possibly <480 Ma period). Finally, the Mountaineer Range Metamorphic Complex, which consists of the Mt. Murchison gneisses-(deformed)Tonalite Belt-Dessent Unit-BSG-BT metasedimentary with TGC, is completed (Figure 14b).

\section{Conclusions}

From the above discussion, the following conclusions can be drawn.

(1) In the Mountaineer Range of NVL, the Ross Orogenic structures such as fold and thrust shear zones formed by dynamothermal metamorphism with regional compression are identified in the Mt. Murchison, Dessent Unit and BSG zone.

(2) The protolith of paragneiss in Mt. Murchison formed during the late Ediacaran to early Cambrian (560-530 Ma), possibly sourced from the Mawson Craton interior and its surrounding orogenic belts (Paleoproterozoic to Mesoproterozoic ages) and Neoproterozoic rift margin hosting the early Ross orogenic products as well; this was transformed into a migmatitic gneiss (SBM173) during the main phase of the Ross Orogeny with a peak temperature stage at around $500 \mathrm{Ma}(498.3 \pm 3.4 \mathrm{Ma})$.

(3) The metamorphic evolution phase of the Dessent Unit is summarized in the $\mathrm{M}_{1}$ (peak pressure), $\mathrm{M}_{2}$ (peak temperature) and $\mathrm{M}_{3}$ (retrograde). The SHRIMP zircon U-Pb ages of 514.6 $\pm 2.0 \mathrm{Ma}$ and 499.2 $\pm 3.4 \mathrm{Ma}$ obtained from amphibolite are comparable to the $\mathrm{M}_{1}$ and $\mathrm{M}_{2}$ stages, respectively. The Dessent Unit underwent intermediate-P/T type metamorphism which is characterized by $10.0-10.5 \mathrm{kbar} / \sim 600^{\circ} \mathrm{C}$ $\left(\mathrm{M}_{1}\right)$ and $\sim 7 \mathrm{kbar} / 700{ }^{\circ} \mathrm{C}\left(\mathrm{M}_{2}\right)$ followed by $4.0-4.5 \mathrm{kbar} / 450{ }^{\circ} \mathrm{C}\left(\mathrm{M}_{3}\right)$.

(4) During the $\mathrm{M}_{2}$ stage of the Dessent Unit, mafic to intermediate igneous rocks intruded the WT/BT boundary regions (tonalite, $499.3 \pm 3.4 \mathrm{Ma}$; hornblende gabbros, $496.2 \pm 1.0$ and $497.6 \pm 1.0$ $\mathrm{Ma}$ ) and is synchronous with the migmatization period of Mt. Murchison (c. $500 \mathrm{Ma}$ ). This indicates that continuous process of fold-shearing-magmatic intrusion-partial melting, which is typically formed in a continental arc orogeny, occurred before and after c. $500 \mathrm{Ma}$ in the Mountaineer Range.

(5) The Dessent Unit corresponds to a tectonic slice sheared between the WT and BT. It is presumed that during the Ross Orogeny, the unit was initially subducted underneath the WT at depth (10.0-10.5 kbar depth, $\sim 35 \mathrm{~km})$ and then thrust into the shallow $(\sim 7 \mathrm{kbar}, \sim 23 \mathrm{~km})$, hot $\left(\geq 700{ }^{\circ} \mathrm{C}\right)$ magmatic arc, docking with the Murchison migmatite terrain.

Supplementary Materials: The following are available online at http://www.mdpi.com/2075-163X/10/10/908/s1, Table S1: SHRIMP zircon U-Pb data for igneous and metamorphic rocks from the Mountaineer Range; Table S2: $\mathrm{P}-\mathrm{T}$ conditions estimated from the Dessent Unit amphibolites using conventional geothermobarometry; Table S3: Representative compositional zoning profile of garnet in the Dessent Unit amphibolites.

Author Contributions: Conceptualization, S.-B.Y., M.J.L. and J.I.L.; methodology, S.-B.Y. and H.K.; formal analysis, S.-B.Y. and H.K.; investigation, S.-B.Y., M.J.L. and J.I.L.; resources, J.I.L.; data curation, S.-B.Y.; writing-original draft preparation, S.-B.Y.; writing-review and editing, all authors; supervision, M.J.L. and J.I.L.; funding acquisition, M.J.L. All authors have read and agreed to the published version of the manuscript.

Funding: This study was supported by the Korea Polar Research Institute (KOPRI) under Grant (PE20200). 
Acknowledgments: We thank Keewook Yi and Shinae Lee (KBSI) for their support with the SHRIMP zircon age dating, Yun Seok Yang (KOPRI) for performing the XRF analyses and In-Sung Yoo (KORPI) for analytical support. Furthermore, we are grateful to Dong Hwa Kim for managing the outdoor safety procedures and supporting the field works, and to Yengkhom Kesorjit Singh for helping to interpret the texture of the sample SB175A (Figure 4a). Two anonymous reviewers are appreciated for their constructive comments and suggestions, which have greatly improved the manuscript. We also thank journal editors for their guidance and for handling of the manuscript.

Conflicts of Interest: The authors declare no conflict of interest.

\section{References}

1. Boger, S.D.; Wilson, C.J.L.; Fanning, C.M. Early Paleozoic tectonism within the East Antarctic craton: The final suture between east and west Gondwana? Geology 2001, 29, 463-466. [CrossRef]

2. Meert, J.G. A synopsis of events related to the assembly of eastern Gondwana. Tectonophysics 2003, 362, 1-40. [CrossRef]

3. Boger, S.D.; Miller, J.M. Terminal suturing of Gondwana and the onset of the Ross-Delamerian Orogeny: The cause and effect of an Early Cambrian reconfiguration of plate motions. Earth Planet. Sci. Lett. 2004, 219, 35-48. [CrossRef]

4. Collins, A.S.; Pisarevsky, S.A. Amalgamating eastern Gondwana: The evolution of the Circum-Indian Orogens. Earth Sci. Rev. 2005, 71, 229-270. [CrossRef]

5. Boger, S.D. Antarctica-Before and after Gondwana. Gondwana Res. 2011, 19, 335-371. [CrossRef]

6. Torsvik, T.H.; Cocks, L.R.M. Gondwana from top to base in space and time. Gondwana Res. 2013, 24, 999-1030. [CrossRef]

7. Fitzsimons, I.C.W. A review of tectonic events in the East Antarctic Shield and their implications for Gondwana and earlier supercontinents. J. Afr. Earth Sci. 2000, 31, 3-23. [CrossRef]

8. Harley, S.L. Archaean-Cambrian crustal development of East Antarctica: Metamorphic characteristics and tectonic implications. In Proterozoic East Gondwana: Supercontinent Assembly and Breakup; Yoshida, M., Windley, B.E., Dasgupta, S., Eds.; Geological Society of London Special Publication: London, UK, 2003; Volume 206, pp. 203-230.

9. Kamenev, E.N.; Maslov, V.A.; Semenov, V.S.; Kurinin, R.G.; Mikhailov, V.M.; Alekseev, N.L.; Kamenev, I.A.; Semenov, S.V. Structure and metamorphism of the Antarctic Shield. Geotectonics 2013, 47, 115-130. [CrossRef]

10. Dalziel, I.W.D. Neoproterozoic-Paleozoic geography and tectonics: Review, hypothesis, environmental speculation. Geol. Soc. Am. Bull. 1997, 109, 16-42. [CrossRef]

11. Cawood, P.A. Terra Australis Orogen: Rodinia breakup and development of the Pacific and Iapetus margins of Gondwana during the Neoproterozoic and Paleozoic. Earth Sci. Rev. 2005, 69, 249-279. [CrossRef]

12. Cawood, P.A.; Buchan, C. Linking accretionary orogenesis with supercontinent assembly. Earth Sci. Rev. 2007, 82, 217-256.

13. Pankhurst, R.J.; Vaughan, A.P.M. The tectonic context of the Early Palaeozoic southern margin of Gondwana. In Early Palaeozoic Peri-Gondwana Terranes: New Insights from Tectonics and Biogeography; Basset, M.G., Ed.; Geological Society of London Special Publication: London, UK, 2009; Volume 325, pp. 171-176.

14. Foden, J.; Elburg, M.A.; Dougherty-Page, J.; Burtt, A. The timing and duration of the Delamerian Orogeny: Correlation with the Ross Orogen and implications for Gondwana assembly. J. Geol. 2006, 114, 189-210.

15. Bomparola, R.M.; Ghezzo, C. Inside the Granite Harbour Intrusives of Northern Victoria Land: Timing and origin of the intrusive sequence. In Online Proceedings of the 10th ISAES X: USGS Open-File Report 2007-1047; Extended Abstract 043; U.S. Geological Survey: Reston, VA, USA; The National Academies: Washington, DC, USA, 2007; 4p.

16. Shaanan, U.; Rosenbaum, G.; Sihombing, F.M.H. Continuation of the Ross-Delamerian Orogen: Insights from eastern Australian detrital-zircon data. Aust. J. Earth Sci. 2017, 65, 1123-1131.

17. Siddoway, C.S. Tectonics of the West Antarctic Rift System: New light on the history and dynamics of distributed intracontinental extension. In Proceedings of the 10th International Symposium on Antarctic Earth Sciences, Santa Barbara, CA, USA, 26 August-1 September 2007; U.S. Geological Survey: Washington, DC, USA, 2008.

18. Burton-Johnson, A.; Riley, T.R. Autochthonous v. accreted terrane development of continental margins: A revised in situ tectonic history of the Antarctic Peninsula. J. Geol. Soc. 2015, 172, 822-835. 
19. Elliot, D.H. The geological and tectonic evolution of the Transantarctic Mountains: A review. In Antarctic Palaeoenvironments and Earth-Surface Processes; Hambrey, M.J., Baker, P.F., Barrett, P.J., Bowman, V., Davies, B., Smellie, J.L., Tranter, M., Eds.; Geological Society of London Special Publication: London, UK, 2013; Volume 381, pp. 7-35.

20. Jordan, T.A.; Riley, T.R.; Siddoway, C.S. The geological history and evolution of West Antarctica. Nat. Rev. Earth Environ. 2020, 1, 117-133.

21. Jokat, W.; Boebel, T.; König, M.; Meyer, U. Timing and geometry of early Gondwana breakup. J. Geophys. Res. 2003, 108, 2848. [CrossRef]

22. Mueller, C.O.; Jokat, W. The initial Gondwana break-up: A synthesis based on new potential field data of the Africa-Antarctica Corridor. Tectonophysics 2019, 750, 301-328.

23. Williams, S.E.; Whittaker, J.M.; Halpin, J.; Müller, R.D. Australian-Antarctic breakup and seafloor spreading: Balancing geological and geophysical constraints. Earth Sci. Rev. 2019, 188, 41-58.

24. Brehrendt, J.C.; LeMasurier, W.E.; Cooper, A.K.; Tessensohn, F.; Trébu, A.; Damaske, D. Geophysical studies of the West Antarctic Rift System. Tectonics 1991, 10, 1257-1273.

25. Granot, R.; Cande, S.C.; Stock, J.M.; Damaske, D. Revised Eocene-Oligocene kinematics for the West Antarctic rift system. Geophys. Res. Lett. 2013, 40, 279-284.

26. Goodge, J.W. Geology and tectonic evolution of the Transantarctic Mountains, from ancient to recent enigma. Gondwana Res. 2020, 80, 5-122.

27. Siddoway, C.S. Antarctica. In Encyclopedia of Geology; Elsevier Science: Amsterdam, The Netherlands, 2020. [CrossRef]

28. Goodge, J.W.; Williams, I.S.; Myrow, P. Provenance of Neoproterozoic and lower Paleozoic siliciclastic rocks of the central Ross orogen, Antarctica: Detrital record of rift-, passive-, and active-margin sedimentation. Geol. Soc. Am. Bull. 2004, 116, 1254-1279. [CrossRef]

29. Goodge, J.W. Metamorphism in the Ross orogeny and its bearing on Gondwan margin tectonics. In Convergent Margin Terranes and Associated Region: A Tribute to W.G. Ernst; Cloos, M., Carlson, W.D., Gibert, M.C., Liu, J.G., Sorensen, S.S., Eds.; Geological Society of America Special Paper: Boulder, CO, USA, 2007; Volume 419, pp. 185-203.

30. Rocchi, S.; Di Vincenzo, G.; Ghezzo, C.; Nardini, I. Granite-Lamprophyre connection in the latest stages of the early Paleozoic Ross Orogeny (Victoria Land, Antarctica). Geol. Soc. Am. Bull. 2009, 121, 801-819. [CrossRef]

31. Rochhi, S.; Bracciali, L.; Gemelli, M.; Ghezzo, C. Arc accretion to the early Paleozoic Antarctic margin of Gondwana in Victoria Land. Gondwana Res. 2011, 19, 594-607.

32. Capponi, G.; Crispini, L.; Meccheri, M. Structural history and tectonic evolution of the boundary between the Wilson and Bowers terranes, Lanterman Range, northen Victoria Land, Antarctica. Tectonophysics 1999, 312, 249-266.

33. Capponi, G.; Kleinschmidt, G.; Pertusati, P.C.; Ricci, C.A.; Tessensohn, F. Terrane relationships in the Mariner Glacier area of Northern Victoria Land, Antarctica. In Aspects of a Suture Zone the Mariner Glacier Area, Antarctica; Tessensohn, F., Ricci, C.A., Eds.; Geologisches Jahrbuch: Hannover, Germany, 2003; Volume B85, pp. 49-78.

34. Ricci, C.A.; Tessensohn, F. The Lanterman-Mariner Suture: Antarctic evidence for active margin tectonics in Paleozoic Gondwana. In Aspects of a Suture Zone the Mariner Glacier Area, Antarctica; Tessensohn, F., Ricci, C.A., Eds.; Geologisches Jahrbuch: Hannover, Germany, 2003; Volume B85, pp. 305-332.

35. Roland, N.W.; Läufer, A.L.; Sossetti, F. Revision of the terrane model of Northern Victoria Land (Antarctica). Terra Antarct. 2004, 11, 55-65.

36. Tessensohn, F.; Hunjes-Kunst, F. Northern Victoria Land terranes, Antarctica: Far-travelled or local products? In Terrane Processes at the Margins of Gondwana; Vaughan, A.P.M., Leat, P.T., Pankhurst, R.J., Eds.; Geological Society of London Special Publications: London, UK, 2005; Volume 246, pp. 275-291.

37. Federico, L.; Capponi, G.; Crispini, L. The Ross Orogeny of the transantarctic mountains: A Northern Victoria Land perspective. Int. J. Earth Sci. 2006, 95, 759-770. [CrossRef]

38. Rosseti, F.; Vignaroli, G.; Di Vincenzo, G.; Gerdes, A.; Ghezzo, C.; Theye, T.; Balsamo, F. Long-Lived orogenic construction along the paleo-Pacific margin of Gondwana (Deep Freeze Range, Northern Victoria Land, Antarctica). Tectonics 2011, 30, TC4008. [CrossRef] 
39. Estrada, S.; Läufer, A.; Eckelmann, K.; Hofmann, M.; Gärtner, A.; Linnemann, U. Continuous Neoproterozoic to Ordovician sedimentation at the East Gondwana margin-Implications from detrital zircons of the Ross Orogen in Northern Victoria Land, Antarctica. Gondwana Res. 2016, 37, 426-448.

40. Stump, E. The Ross Orogen of the Transantarctic Mountains; Cambridge University Press: Cambridge, UK, 2010; 308p.

41. Kleinschmidt, P.B.; Tessensohn, F. Early Paleozoic westward directed subduction at the Pacific continental margin of Antarctica. In Gondwana Sixth: Structure, Tectonics, and Geophysics; Geophysical Monograph; McKenzie, G.D., Ed.; American Geophysical Union: Washington, DC, USA, 1987; Volume 40, pp. 89-105.

42. Federico, L.; Crispini, L.; Capponi, G.; Bradshaw, J.D. The Cambrian Ross Orogeny in Northern Victoria Land (Antarctica) and New Zealand: A synthesis. Gondwana Res. 2009, 15, 188-196.

43. Capponi, G.; Meccheri, M.; Oggiano, G.; Casnedi, R.; Crispini, L.; Kleinschmidt, G.; Montrasio, A.; Pertusati, P.C.; Roland, N.W.; Salvini, F.; et al. Antarctic Geological 1:250,000 Map Series, Coleman Island Quadrangle (Victoria Land); Museo Nazionale dell'Antartide, Sezione di Scienze della Terra: Siena, Italy, 1997.

44. Capponi, G.; Meccheri, M.; Pertusati, P.C.; Castelli, D.; Crispini, L.; Kleinschmidt, G.; Lombardo, B.; Montrasio, A.; Musumeci, G.; Oggiano, G.; et al. Antarctic Geological 1:250,000 Map Series, Mount Murchison Quadrangle (Victoria Land); Museo Nazionale dell'Antartide, Sezione di Scienze della Terra: Siena, Italy, 1997.

45. GANOVEX Team. Geological Map of North Victoria Land, Antarctica, 1:500,000_Explanary Notes; Geologisches Jahrbuch: Hannover, Germany, 1987; Volume B66, pp. 7-79.

46. Henjes-Kunst, F.; Schüssler, U. Metasedimentary units of the Cambro-Ordovician Ross Orogen in Nothern Victoria Land and Oates Land: Implications for their provenance and goetectonic setting from geochemical and Nd-Sr isotope data. Terra Antarct. 2003, 10, 105-128.

47. Paulsen, T.S.; Deering, C.; Slivinski, J.; Bachmann, O.; Guilong, M. Detrital zircon ages from the Ross Supergroup, Northern Victoria Land, Antarctica: Implications for the tectonostratigraphic evolution of the Pacific-Gondwana margin. Gondwana Res. 2016, 35, 79-96. [CrossRef]

48. Kim, Y.; Kim, T.; Lee, J.I.; Kim, S.J. SHRIMP U-Pb ages of zircon from banded gneisses and leucocratic dyke in the Wilson Terrane, Northern Victoria Land, Antarctica. J. Geol. Soc. Korea 2017, 53, 489-507. (In Koran) [CrossRef]

49. Rocchi, S.; Di Vincenzo, G.; Ghezzo, C. The Terra Nova Intrusive Complex (Victoria Land, Antarctica); Terra Antarctic Reports; Terra Antarctic Publication: Genova, Italy, 2004; Volume 10, 50p.

50. Bomparola, R.M.; Ghezzo, C.; Belousova, E.; Griffin, W.L.; O'Reilly, S.Y. Resetting of the U-Pb zircon system in Cambro-Ordovician intrusives of the Deep Freeze Range, Northern Victoria Land, Antarctica. J. Petrol. 2007, 48, 327-364.

51. Giacomini, F.; Tiepolo, M.; Dallai, L.; Ghezzo, C. On the onset and evolution of the Ross-orogeny magmatism in North Victoria Land-Antarctica. Chem. Geol. 2007, 240, 103-128. [CrossRef]

52. Yi, S.B.; Lee, M.J.; Park, S.-H.; Han, S.; Yang, Y.S.; Choi, H. Occurrence of ice-rafted erratics and the petrology of the KR1 seamount trail from the Australian-Antarctic Ridge. Int. Geol. Rev. 2019, 61, 1429-1445.

53. Foster, D.A.; Goscombe, B.D. Continental growth and recycling in convergent orogens with large turbidite fans on oceanic crust. Geosciences 2013, 3, 354-388.

54. Estrada, S.; Jordan, H. Early Paleozoic Island Arc Volcanism in the Bowers Terrane of Northern Victoria Land, Antarctica; Geologisches Jahrbuch: Hannover, Germany, 2003; Volume B95, pp. 183-207.

55. Meccheri, M.; Pertusati, P.C.; Tessensohn, F. Explanatory notes to the geological and structural map of the area between the Aviator Glacier and Victory Mountains, Northern Victoria Land, Antarctica. In Aspects of a Suture Zone the Mariner Glacier Area, Antarctica; Tessensohn, F., Ricci, C.A., Eds.; Geologisches Jahrbuch: Hannover, Germany, 2003; Volume B85, pp. 9-33.

56. Buggisch, W.; Kleinschmidt, G. Recovery and recrystallization of quartz and "crystallinity" of illite in the Bowers and Robertson Bay terranes, Northern Victoria Land, Antarctica. In Geological Evolution of Antarctica; Thomson, M.R.A., Crame, J.A., Thomson, J.W., Eds.; Cambridge University Press: Cambridge, UK, 1991; pp. 155-160.

57. Palmeri, R.; Ghiribelli, B.; Ranalli, G.; Talarico, F.; Ricci, C.A. Ultrahigh-Pressure metamorphism and exhumation of garnet-bearing ultramafic rocks from the Lanterman Range (Northern Victoria Land, Antarctica). J. Metamorph. Geol. 2007, 25, 225-243. [CrossRef]

58. Palmeri, R.; Talarico, F.M.; Ricci, C.A. Ultrahigh-Pressure metamorphism at the Lanterman Range (northern Victoria Land, Antarctica). Geol. J. 2011, 46, 126-136. 
59. Palmeri, R.; Sandroni, S.; Godard, G.; Ricci, C.A. Boninite-Derived amphibolites from the Lanterman-Mariner suture (northern Victoria Land, Antarctica): New geochemical and petrological data. Lithos 2012, 140-141, 200-223. [CrossRef]

60. Di Vincenzo, G.; Horton, F.; Paleri, R. Protracted ( 30 Ma) eclogite-facies metamorphism in northern Victoria Land (Antarctica): Implications for the geodynamics of the Ross/Delamerian Orogen. Gondwana Res. 2016, 40, 91-106. [CrossRef]

61. Kim, T.; Kim, Y.; Cho, M.; Lee, J.I. P-T evolution and episodic zircon growth in barroisite eclogites of the Lanterman Range, northern Victoria Land, Antarctica. J. Metamorph. Geol. 2019, 37, 509-537. [CrossRef]

62. Scambelluri, M.; Messiga, B.; Vannucci, R.; Villa, I.M. Petrology, geochemistry and geochronology of the Dessent Unit, northern Victoria Land, Antarctica: Some constraints on its evolutionary history. In Aspects of a Suture Zone the Mariner Glacier Area, Antarctica; Tessensohn, F., Ricci, C.A., Eds.; Geologisches Jahrbuch: Hannover, Germany, 2003; Volume B85, pp. 95-131.

63. Capponi, G.; Carosi, R.; Meccheri, M. Strain analysis in the Millen Range of Northern Victoria Land, Antarctica. In Aspects of a Suture Zone the Mariner Glacier Area, Antarctica; Tessensohn, F., Ricci, C.A., Eds.; Geologisches Jahrbuch: Hannover, Germany, 2003; Volume B85, pp. 225-251.

64. Di Vincenzo, G.; Grande, A.; Rossetti, F. Paleozoic silisiclastic rocks from northern Victoria Land (Antarctica): Provenance, timing of deformation, and implications for the Antarctica-Australia connection. Geol. Soc. Am. Bull. 2014, 126, 1416-1438. [CrossRef]

65. Tiepolo, M.; Tribuzio, R. Petrology and U-Pb zircon geochronology of amphibole-rich cumulates with sanukitic affinity from Husky Ridge (Northern Victoria Land, Antarctica): Insights into the role of amphibole in the petrogenesis of subduction-related magmas. J. Petrol. 2008, 49, 937-970.

66. Kleinschmidt, G.; Roland, N.W.; Schubert, E.S. The metamorphic basement complex in the Mountaineer Range, North Victoria Land, Antarctica. In German Antarctic North Victoria Land Expedition 1982/83, GANOVEX III, Vol. I.; Roland, N.W., Ed.; Geologisches Jahrbuch: Hannover, Germany, 1984; Volume B60, pp. $213-251$.

67. Flöttmann, T. The Kyanite Wall shear zone-Evidence for a mid-crustal ductile detachment zone at the south-central Wilson Terrane margin, Antarctica. In Aspects of a Suture Zone the Mariner Glacier Area, Antarctica; Tessensohn, F., Ricci, C.A., Eds.; Geologisches Jahrbuch: Hannover, Germany, 2003; Volume B85, pp. 81-92.

68. Gibson, G.M.; Tessensohn, F.; Crawford, A. Bowers supergroup rocks west of the Mariner Glacier and possible greenschist facies equivalents. In GANOVEX III; Roland, N.W., Ed.; Geologisches Jahrbuch: Hannover, Germany, 1984; Volume B1, pp. 117-141.

69. Bracciali, L.; Di Vincenzo, G.; Rocchi, S.; Ghezzo, C. The Tiger Gabbro from northern Victoria Land, Antarctica: The root of an island arc within the early Palaeozoic margin of Gondwana. J. Geol. Soc. Lond. 2009, 166, 711-724. [CrossRef]

70. Henjes-Kunst, F.; Koepke, J.; Läufer, A.; Estrada, S.; Phillips, G.; Piepjohn, K.; Kosanke, D. The Ross-orogenic Tiger Gabbro Complex (Northern Victoria Land, Antarctica): Insight into the lower crust of a Cambrian island arc. Polarforschung 2014, 84, 23-38.

71. Engel, S. Contact Metamorphism by the Layered Gabbro at Spatulate Ridge and Apostrophe Island, North Victoria Land, Antarctica; Geologisches Jahrbuch: Hannover, Germany, 1987; Volume B66, pp. 275-301.

72. Han, G.U. Geochemistry, Sr-Nd Isotopes, and Zircon U-Pb Ages of Gabbroic Rocks from the Tiger Gabbro Complex, Northern Victoria Land, Antarctica. Master's Dissertation, Chungbuk National Univeristy, Cheongju, Korea, 2020; 57p.

73. Williams, I.S. U-Th-Pb geochronology by ion microprobe. In Applications of Microanalytical Techniques to Understanding Mineralizing Processes; Reviews in Economic Geology; McKibben, M.A., Shanks, W.C.P., Ridley, W.I., Eds.; Society of Economic Geologists: Littleton, CO, USA, 1998; Volume 7, pp. 1-35.

74. Ireland, T.R.; Williams, I.S. Considerations in zircon geochronology by SIMS. In Zircon; Reviews in Mineralogy and Geochemistry; Hanchar, J.M., Hoskin, P.W.O., Eds.; Mineralogical Society of America: Chantilly, VA, USA, 2003; Volume 53, pp. 215-241.

75. Claoué-Long, J.C.; Compston, W.; Roberts, J.; Fanning, C.M. Two Carboniferous ages: A comparison of SHRIMP zircon dating with conventional zircon ages and ${ }^{40} \mathrm{Ar} /{ }^{39} \mathrm{Ar}$ analysis. In Geochronology, Time Scales and Global Stratigraphic Correlation; Berggren, W.A., Kent, D.V., Aubry, M.-P., Hardenbol, J., Eds.; Society for Sedimentary Geology Special Publication: Tulsa, OK, USA, 1995; Volume 54, pp. 3-21. 
76. Paces, J.B.; Miller, J.D. Precise U-Pb ages of Duluth Complex and related mafic intrusions, northeastern Minnesota: Geochronological insights to physical, petrogenetic, paleomagnetic, and tectonomagmatic processes associated with the 1.1 Ga Midcontinent Rift system. J. Geophys. Res. 1993, 98, 13997-14013. [CrossRef]

77. Steiger, R.; Jäger, E. Subcommission of geochronology: Convention on the use of decay constants in geoand cosmo-chronology. Earth Planet. Sci. Lett. 1977, 36, 359-362. [CrossRef]

78. Ludwig, K.R. User's Manual for Isoplot/Ex Version 3.0: A Geochronological Toolkit for Microsoft Excel; Berkeley Geochronology Center Special Publication: Berkeley, CA, USA, 2003; Volume 4, 70p.

79. Connolly, J.A.D. Multivariable phase diagrams: An algorithm based on generalized thermodynamics. Am. J. Sci. 1990, 290, 666-718. [CrossRef]

80. Holland, T.J.B.; Powell, R. An internally consistent thermodynamic data set for phases of petrological interest. J. Metamorph. Geol. 1998, 16, 309-343.

81. Newton, R.C.; Charlu, T.V.; Kleppa, O.J. Thermochemistry of the high structural state plagioclases. Geochim. Cosmochim. Acta 1980, 44, 933-941. [CrossRef]

82. Powell, R.; Holland, T. Relating formulations of the thermodynamics of mineral solid solutions: Activity modeling of pyroxenes, amphiboles, and micas. Am. Mineral. 1999, 84, 1-14. [CrossRef]

83. White, R.W.; Powell, R.; Holland, T.J.B.; Worley, B.A. The effect of $\mathrm{TiO}_{2}$ and $\mathrm{Fe}_{2} \mathrm{O}_{3}$ on metapelitic assemblages at greenschist and amphibolite facies conditions: Mineral equilibria calculations in the system $\mathrm{K}_{2} \mathrm{O}-\mathrm{FeO}-\mathrm{MgO}-\mathrm{Al}_{2} \mathrm{O}_{3}-\mathrm{SiO}_{2}-\mathrm{H}_{2} \mathrm{O}-\mathrm{TiO}_{2}-\mathrm{Fe}_{2} \mathrm{O}_{3}$. J. Metamorph. Geol. 2000, 18, 497-511. [CrossRef]

84. Auzanneau, E.; Schmidt, M.W.; Vielzeuf, D.; Connolly, J.A.D. Titanium in phengite: A geobarometer for high temperature eclogites. Contrib. Mineral. Petrol. 2010, 159, 1-24.

85. Coggon, R.; Holland, T.J.B. Mixing properties of phengitic micas and revised garnet-phengite thermobarometers. J. Metamorph. Geol. 2002, 20, 683-696. [CrossRef]

86. Holland, T.J.B.; Powell, R. Thermodynamics of order-disorder in minerals 2. Symmetric formalism applied to solid solutions. Am. Mineral. 1996, 81, 1425-1437. [CrossRef]

87. Holland, T.J.B.; Baker, J.; Powell, R. Mixing properties and activity-composition relationships of chlorites in the system $\mathrm{MgO}-\mathrm{FeO}-\mathrm{Al}_{2} \mathrm{O}_{3}-\mathrm{SiO}_{2}-\mathrm{H}_{2} \mathrm{O}$. Eur. J. Mineral. 1998, 10, 395-406. [CrossRef]

88. Dale, J.; Powell, R.; White, R.W.; Elmer, F.L.; Holland, T.J.B. A thermodynamic model for Ca-Na clinoamphiboles in $\mathrm{Na} 2 \mathrm{O}-\mathrm{CaO}-\mathrm{FeO}-\mathrm{MgO}-\mathrm{Al}_{2} \mathrm{O}_{3}-\mathrm{SiO}_{2}-\mathrm{H}_{2} \mathrm{O}-\mathrm{O}$ for petrological calculations. J. Metamorph. Geol. 2005, 23, 771-791. [CrossRef]

89. Holland, T.J.B.; Powell, R. Calculation of phase relations involving haplogranitic melts using an internally consistent thermodynamic dataset. J. Petrol. 2001, 42, 673-683. [CrossRef]

90. White, R.W.; Powell, R.; Holland, T.J.B. Calculation of partial melting equilibria in the system $\mathrm{Na}_{2} \mathrm{O}-\mathrm{CaO}-\mathrm{K}_{2} \mathrm{O}-\mathrm{FeO}-\mathrm{MgO}-\mathrm{Al}_{2} \mathrm{O}_{3}-\mathrm{SiO}_{2}-\mathrm{H}_{2} \mathrm{O}$ (NCKFMASH). J. Metamorph. Geol. 2001, 19, 139-153. [CrossRef]

91. Indares, A.; Martignole, J. Biotite-garnet geothermometry in the granulite facies: The influence of Ti and $\mathrm{Al}$ in biotite. Am. Mineral. 1985, 70, 272-278.

92. Graham, C.M.; Powell, R. A garnet-hornblende geothermometer: Calibration, testing, and application to the Pelona schist, southern California. J. Metamorph. Geol. 1984, 11, 717-733. [CrossRef]

93. Perchuk, L.L. Metamorphic evolution of shields and fold-belts. Geol. Zb. Geol. Carpathica 1985, 36, 179-189.

94. Hoish, T.D. Empirical calibration of six geobarometers for the mineral assemblage quartz + muscovite + biotite + plagioclase + garnet. Contrib. Mineral. Petrol. 1990, 104, 225-234. [CrossRef]

95. Kohn, M.J.; Spear, F.S. Empirical calibration of geobarometers for the assemblage garnet + hornblende + plagioclase + quartz. Am. Mineral. 1989, 74, 77-84.

96. Kohn, M.J.; Spear, F.S. Two new barometers for garnet amphibolites with applications to eastern Vermont. Am. Mineral. 1990, 75, 89-96.

97. Capponi, G.; Messiga, B.; Piccardo, G.B.; Scambelluri, M.; Traverso, G.; Vannucci, R. Metamorphic assemblages in layered amphibolites and micaschists from the Dessent Formation (Mountaineer Range, Antarctica). Mem. Soc. Geol. Ital. 1990, 43, 87-95.

98. Castelli, D.; Oggiano, G.; Talarico, F.; Belluso, E.; Colombo, F. Mineral chemistry and petrology of the Wilson Terrane metamorphics from Retreat Hills to Lady Newnes Bay, Northern Victoria Land, Antarctica. In Aspects of a Suture Zone the Mariner Glacier Area, Antarctica; Tessensohn, F., Ricci, C.A., Eds.; Geologisches Jahrbuch: Hannover, Germany, 2003; Volume B85, pp. 135-171. 
99. Plyusnnina, L.P. Geothermometry and geobatometry of plagioclase-hornblende bearing assemblages. Contrib. Mineral. Petrol. 1982, 80, 140-146.

100. Ernst, W.G. Coexisting sodic and calcic amphiboles from high pressure metamorphic belts and the stability of barroisitic amphibole. Mineral. Mag. 1979, 43, 269-278. [CrossRef]

101. Spear, F.S. An experimental study of hornblende stability and compositional variability in amphibole. Am. J. Sci. 1981, 281, 697-734.

102. Bucher, K.; Frey, M. Petrogenesis of Metamorphic Rocks; Springer: Berlin, Germany, 2002; 349p.

103. Oh, C.W.; Liu, J.G. A petrogenetic grid for eclogite and related facies under high-pressure metamorphism. Isl. Arc 1998, 7, 36-51.

104. Foster, D.A.; Gray, D.R.; Spaggiari, C.; Kamenov, G.; Bierlein, F.P. Paleozoic Lachlan orogeny, Australia; accretion and construction of continental crust in a marginal ocean setting: Isotopic evidence from Cambrian metavolcanic rocks. In Earth Accretionary Systems in Space and Time; Cawood, P.A., Kröner, A., Eds.; Geological Society of London Special Publication: London, UK, 2009; Volume 318, pp. 329-349.

105. Cayley, R.A. Exotic crustal block accretion to the eastern Gondwanaland margin in the Late Cambrian-Tasmania, the Selwyn Block, and implications for the Cambrian-Silurian evolution of the Ross, Delamerian, and Lachlan orogens. Gondwana Res. 2011, 19, 628-649. [CrossRef]

106. Aitken, A.R.A.; Betts, P.G.; Young, D.A.; Blankenship, D.D.; Roberts, J.L.; Siegert, M.J. The Australo-Antarctic Columbia to Gondwana transition. Gondwana Res. 2016, 29, 136-152. [CrossRef]

107. Goodge, J.W. From Rodinia to Gondwana: Supercontinent evolution in the Transantarctic Mountains. In Antarctica at the Close of a Millennium, Proceedings of the 8th International Symposium on Antarctic Earth Science, Wellington, New Zealand, July 1999; Gamble, J., Skinner, D.A., Henrys, S., Eds.; Royal Society of New Zealand Bulletin: Wellington, New Zealand, 2002; Volume 65, pp. 61-74.

108. Goodge, J.W.; Myrow, P.; Williams, I.S.; Bowring, S.A. Age and provenance of the Beardmore Group, Antarctica: Constrains on Rodinia supercontinent breakup. J. Geol. 2002, 110, 393-406. [CrossRef]

109. Cooper, A.F.; Maas, R.; Scott, J.M.; Barber, A.J.W. Dating of volcanism and sedimentation in the Skelton Group, Transantarctic Mountains; implications for the Rodinia-Gondwana transition in southern Victoria Land, Antarctica. Geol. Soc. Am. Bull. 2011, 123, 681-702.

110. Hagen-Peter, G.; Cottle, J.M.; Smit, M.; Cooper, A.F. Coupled garnet Lu-Hf and monazite U-Pb geochronology constrain early convergent margin dynamics in the Ross Orogeny, Antarctica. J. Metamorph. Geol. 2016, 34, 293-319.

111. Goodge, J.W.; Fanning, C.M.; Norman, M.D.; Bennett, V.C. Temporal, isotopic and spatial relations of early Paleozoic Gondwana-margin arc magmatism, central Transantarctic Mountains, Antarctica. J. Petrol. 2012, 53, 2027-2065.

112. Rino, S.; Kon, Y.; Sato, W.; Maruyama, S.; Santosh, M.; Zhao, D. The Grenvillian and Pan-African orogeny: World's largest orogenies through geologic time, and their implications on the origin of superplume. Gondwana Res. 2008, 14, 51-72. [CrossRef]

113. Capponi, G.; Castelli, D.; Fioretti, A.; Oggiano, G. Geological mapping and field relationships of eclogites from the Landterman Range (Northern Victoria Land, Antarctica). In The Antarctic Region: Geological Evolution and Processes; Ricci, C.A., Ed.; Terra Antarctica Publication: Siena, Italy, 1997; pp. 219-225.

114. Ghiribelli, B.; Frezzotti, M.L.; Palmeri, R. Coesite in eclogites of the Lanterman Range (Antarctica): Evidence from textural and Raman studies. Eur. J. Mineral. 2002, 14, 355-360. [CrossRef]

115. Castro, A.; Corretgé, L.G.; Rosa, J.D.D.; Fernández, C.; López, S.; Garcia-Moreno, O.; Chacón, H. The appinite-migmatite complex of Sanabria, NW Iberian Massif, Spain. J. Petrol. 2003, 44, 1309-1344. [CrossRef]

116. Murphy, J.B. Appinite suites: A record of the role of water in the genesis, transport, emplacement and crystallization of magma. Earth Sci. Rev. 2013, 119, 35-59. [CrossRef]

117. Murphy, J.B. Appinite suites and their genetic relationship with coeval voluminous granitoid batholiths. Int. Geol. Rev. 2020, 62, 683-713. [CrossRef]

118. Yi, S.-B.; Oh, C.W.; Lee, S.-Y.; Choi, S.-G.; Kim, T.; Yi, K. Triassic mafic and intermediate magmatism associated with continental collision between the North and South China Cratons in the Korean Peninsula. Lithos 2016, 246-247, 149-164. [CrossRef] 
119. Yi, S.-B.; Oh, C.W.; Choi, S.-G.; Seo, J. A study on the Mesozoic Magmatism in the Dangjin Area, Western Gyeonggi Massif, Korea. J. Petrol. Soc. Korea 2019, 28, 85-109. (In Korean)

120. Zhang, X.; Xue, F.; Yuan, L.; Ma, Y.; Wilde, S.A. Late Permian appinite-granite complex from northwestern Liaoning, North China Craton: Petrogenesis and tectonic implications. Lithos 2012, 155, 201-217. [CrossRef] 